\title{
Virtual screening and molecular docking of structures with potential inhibitor of the
} ebolavirus glycoprotein

\author{
Triagem virtual e ancoragem molecular de estruturas com potencial inibidor da glicoproteína do \\ ebolavírus \\ Proyección virtual y acoplamiento molecular de estructuras con potencial inhibitorio de la \\ glicoproteína del ébolavirus
}

Received: 01/21/2022 | Reviewed: 01/29/2022 | Accept: 01/30/2022 | Published: 01/31/2022

Maria de Lourdes de Aguiar Silva Ferreira ORCID: https://orcid.org/0000-0002-1964-7926 Federal University of Maranhão, Brazil E-mail: lurdes.mdlf8@gmail.com Ruan Sousa Bastos

ORCID: https://orcid.org/0000-0003-3585-1596 Federal University of Pará, Brazil Research Group in Medicinal Chemistry and Biotechnology, Brazil Modeling and Computational Chemistry Laboratory, Brazil E-mail: sonruanquimica@gmail.com Lúcio Rocha de Lima

ORCID: https://orcid.org/0000-0002-2187-6154 Federal University of Amapá, Brazil Modeling and Computational Chemistry Laboratory, Brazil E-mail: luciorolima@gmail.com

Edielson dos Santos Barbosa

ORCID: https://orcid.org/ 0000-0001-6863-5596 Federal University of Pará, Brazil E-mail: EdiUFPA@outlook.com

Ionara Nayana Gomes Passos

ORCID: https://orcid.org/0000-0003-4729-4977

Federal University of Maranhão, Brazil Research Group in Natural Sciences and Biotechnology, Brazil
E-mail: ionara.passos@gmail.com

Cleydson Breno Rodrigues dos Santos

ORCID: https://orcid.org/0000-0002-0271-335X Federal University of Amapá, Brazil Modeling and Computational Chemistry Laboratory, Brazil E-mail: breno@unifap.br

Janilson Lima Souza

ORCID: https://orcid.org/0000-0002-5518-9985 Federal Institute of Education, Science and Technology of Maranhão, Brazil Chemistry Research Group, Brazil E-mail: janilsonlima@ifma.edu.br

Ulisses Alves do Rego

ORCID: https://orcid.org/ 0000-0002-7717-9382 Federal University of Maranhão, Brazil Research Group in Natural Sciences and Biotechnology, Brazil

\begin{abstract}
Ebola is a disease caused by viruses of the ebolavirus genus that cause hemorrhagic fever with high human mortality. Symptoms of the infection include fever, headache, joint pain, diarrhea, vomiting and stomach pain. Unfortunately, there is still no effective treatment for this disease. This work aimed to perform a virtual screening of candidates with EBOV GP inhibition potential based on pharmacophores of 4 structures from the literature. The selected candidates underwent ADME analysis and later calculations of HOMO, LUMO and electrostatic potential map. 50 structures were obtained and after selection based on their ADME characteristics only 4 candidates were chosen. In the molecular anchoring process, the structure that presented the best binding energy was ZINC12 with $-4.44 \mathrm{kcal}^{\mathrm{mol}}{ }^{-1}$
\end{abstract}


and enzyme inhibition constant $\mathrm{Ki}$ equal to $555.9 \mu \mathrm{M}$. This result is fundamental, as it will subsidize other researches such as in vitro studies, or even application in real samples.

Keywords: EBOV GP; Virtual screening; Docking molecular.

\section{Resumo}

O ebola é uma doença causada por vírus do gênero ebolavírus que ocasionam febre hemorrágica com alta mortalidade humana. Os sintomas da infecção compreendem febre, dor de cabeça, dores nas articulações, diarreia, vômito e dor de estômago. Infelizmente, ainda não existe tratamento eficaz para esta doença. Este trabalho teve como objetivo realizar a triagem virtual de candidatos com potencial de inibição da EBOV GP baseada em farmacóforos de 4 estruturas da literatura. Os candidatos selecionados passaram por analise ADME e posteriormente cálculos de HOMO, LUMO e mapa de potencial eletrostático. 50 estruturas foram obtidas e após seleção com bases nas suas características ADME somente 4 candidatos foram escolhidos. No processo de ancoragem molecular a estrutura que apresentou a melhor energia de ligação foi a ZINC12 com $-18.59 \mathrm{~kJ} \mathrm{~mol}^{-1}$ e constante de inibição enzimática Ki igual a $555.9 \mu \mathrm{M}$. Este resultado é fundamental, pois subsidiará outras pesquisas tais como estudos de in vitro, ou mesmo aplicação em amostras reais.

Palavras-chave: EBOV GP; Triagem virtual; Ancoragem molecular.

\section{Resumen}

El Ébola es una enfermedad causada por virus del género ébolavirus que causan fiebre hemorrágica con alta mortalidad humana. Los síntomas de la infección incluyen fiebre, dolor de cabeza, dolor en las articulaciones, diarrea, vómitos y dolor de estómago. Desafortunadamente, todavía no existe un tratamiento efectivo para esta enfermedad. Este trabajo tuvo como objetivo realizar un proyección virtual de candidatos con potencial para inhibir EBOV GP basado en farmacóforos de 4 estructuras de la literatura. Los candidatos seleccionados se sometieron a análisis ADME y posteriores cálculos de HOMO, LUMO y mapa de potencial electrostático. Se obtuvieron 50 estructuras y tras la selección en base a sus características ADME solo se eligieron 4 candidatas. En el proceso de acoplamiento molecular, la estructura que presentó mejor energía de unión fue ZINC12 con $-18.59 \mathrm{~kJ}^{\mathrm{m} \mathrm{mol}^{-1}}$ y constante de inhibición enzimática $\mathrm{Ki}$ igual a $555.9 \mu \mathrm{M}$. Este resultado es fundamental, ya que subsidiará otras investigaciones como estudios in vitro, o incluso su aplicación en muestras reales.

Palabras clave: EBOV GP; Proyección virtual; Acoplamiento molecular.

\section{Introduction}

Ebola is a disease caused by viruses of the ebolavirus genus that cause headache, joint and muscle pain, diarrhea, vomiting, stomach pain. In some cases, those infected may present with a rash and bleeding, in addition to hemorrhagic fever with high human mortality (Khabbaz et al., 2015; Breman et al., 2016). These viruses were discovered in the 1970s and are part of the Filoviridae family, infectious viruses such as Marburg and Cueva-virus. This family is known for its filamentous characteristics (Figure 1), are negative strand RNA viruses (Rougeron et al., 2015; Towner et al., 2007), are highly pathogenic and are classified as "risk class 4" of according to the World Health Organization (WHO) (World Health Organization, 2020; Mali \& Chaudhari, 2019; Baize et al., 2014; Feldmann \& Geisbertet, 2011).

Figure 1 - Schematic representation of the Ebola virus.

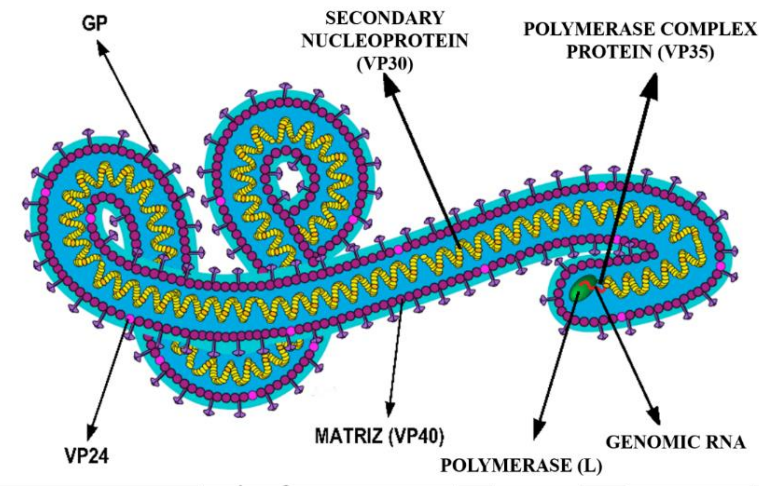

Source: Adapted from Ian M. Mackay, PhD, available on the blog: http://virologydownunder.blogspot.com.br/ 
Research, Society and Development, v. 11, n. 2, e45311226034, 2022

(CC BY 4.0) | ISSN 2525-3409 | DOI: http://dx.doi.org/10.33448/rsd-v11i2.26034

Recent Ebola cases were presented by the WHO demonstrating that between 2018 - 2020 in the Democratic Republic of Gong Zaire there were 3,481 new cases, causing the death of 2,299 people, thus presenting $66 \%$ fatality during this period (World Health Organization, 2020). During these outbreaks the effectiveness of some drugs were tested to fight the virus, such as clinical trials in Guinea. The rVSV-ZEBOV vaccine was studied as a way to prevent new outbreaks of the disease, people who received the vaccine did not show infection during 10 days of investigation, in the same period of time 23 people who were not vaccinated showed infection. This vaccine is still being used to control the disease in the Republic of Congo, therefore, the WHO still recognizes the need to evaluate new candidate vaccines to combat the Ebola virus (World Health Organization, 2020). While there are several candidates for an Ebola vaccine (Richman \& Nathanson, 2016), there is still no evidence of effective treatment for people already afflicted with the disease.

It is believed that the Ebola virus can be transmitted between humans and/or animals through contact with the body fluids of those already infected. An illustrative scheme of the possible viral cycle of the disease is illustrated in Figure 2. Humans and other mammalian species are definitive hosts of the Ebola virus, and endemic areas are investigative foci of the disease. (World Health Organization, 2020; Feldmann \& Geisbertet, 2011). In view of studies carried out to identify the natural reservoirs in Ebola hemorrhagic fever outbreaks, experiments carried out with African plants and animals have shown that rodents and bats are possible foci of the Ebola virus (Baize et al., 2014).

Figure 2 - Ebola virus transmission cycle.

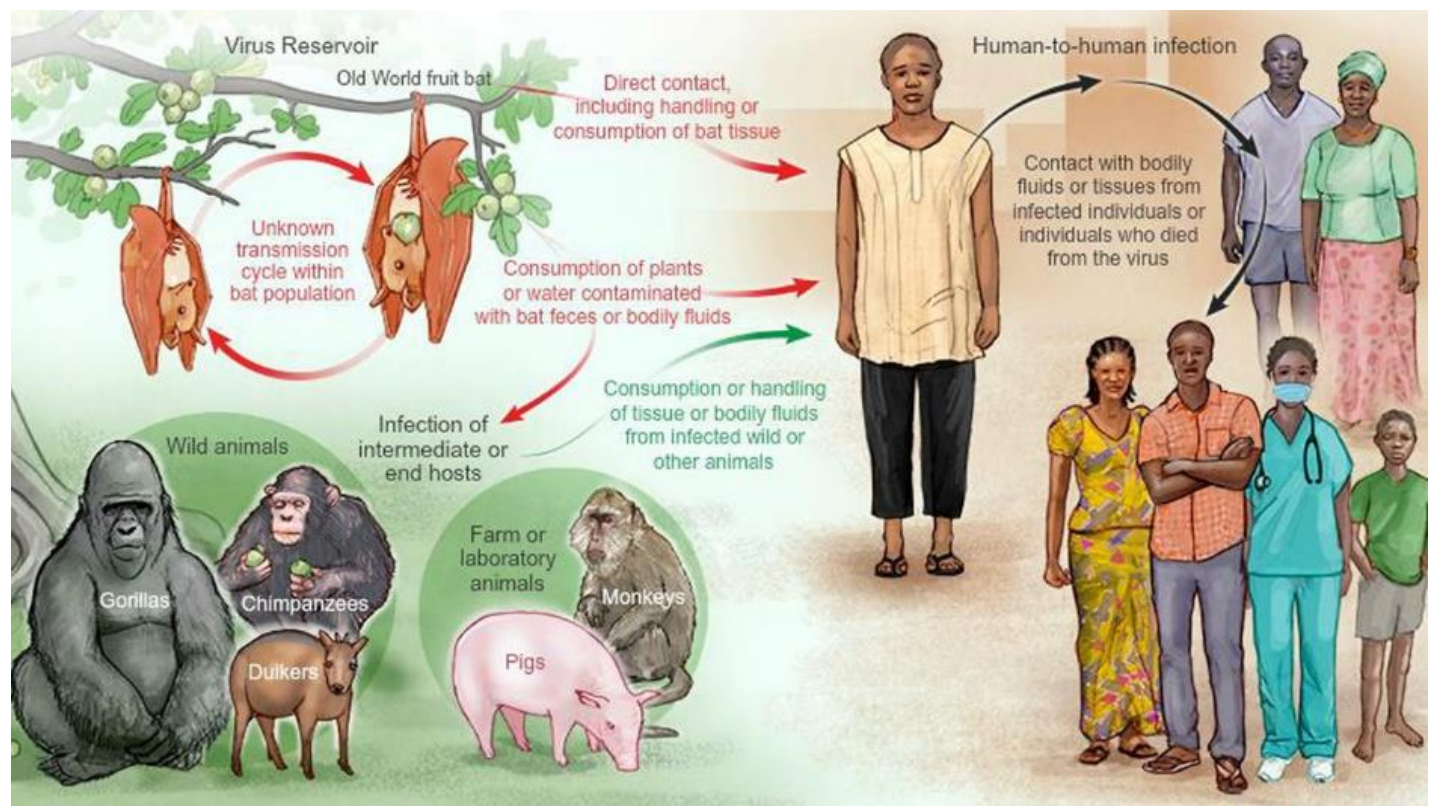

Source: Massachusetts Medical Society, available on the site: https://biology.stackexchange.com/

Four drugs, benzatropine, bepridil, paroxetine and sertraline were investigated by Ren et al. (2018) for the inhibition of Ebola virus infections with action on glycoprotein. These drugs already exist on the market, and therefore, the side effects, pharmacokinetics and pharmacology are already known.

Benzotropine is an anticholinergic drug, known as an acetylcholine receptor antagonist (Jacoby, 2017), is a drug used for the treatment of symptoms related to Parkinson's disease (Johns, 2014), and cocaine addicts, as it acts as a dopamine inhibitor based on GBR12909 (Rothman et al., 2008).

The drug bepridil is used in the treatment of dysrhythmia by blocking the sodium current and expelling calcium from cardiac cells. One of the adverse effects of the use of this drug is a ventricular arrhythmia ("spins of the tips") (Desai, 2016). In 
an isolated case, pneumonia caused by the use of bepridil was observed in a 78-year-old man (Yokoi et al., 2013).

Paroxetine and Sertraline are inhibitors that act on serotonin reuptake acting as a drug with antidepressant action, their performance is low in terms of noradrenaline reuptake (Van Harten, 1993). Both drugs generate collective effects such as nausea, dizziness, insomnia and irritation (Desai, 2016). The use of paroxetine associated with tamixifen (estrogen receptor) causes a decrease in this, as it acts as a strong inhibitor of cytochrome P450 2D6, the study was carried out with 30 breast cancer survivors (Loprinzi et al., 2011).

Virtual screening is a computational methodology aimed at accelerating the discovery of new drugs. This computational methodology uses several methods to evaluate and direct choices of chemical structures with modulated biological applications, that is, it facilitates the scientific investigation of possible drug candidates (Dos Santos et al., 2020; Wermuth et al., 2015).

Molecular Docking uses computational processes that provide estimates of ligand-protein free energy. For this, several spatial conformations of the complex are obtained, making it possible to evaluate the most stable conformation (lower energy) and the greater inhibitory effect (higher enzyme inhibition constant) (Souza, 2015).

Computational chemistry has brought innovations to several fields of investigation, its contributions include several theoretical approaches, using methods ranging from mechanical calculations to ab initio calculations such as the Density Functional Theory. It can be used to obtain the molecular optimization of different structures, obtain vibrational spectra, evaluate bond angles and distances, thus aiming to explore all possible molecular characteristics through computational tools (Ault, 2018; Larkin, 2017; Nova \& Maseras , 2013).

In this work, a pharmacophore-based virtual screening was performed to search for potential inhibitors of EBOV GP, responsible for binding to the host cell receptor that leads to membrane fusion (Ren et al., 2018). In addition, the pharmacokinetic and toxicological properties of the molecules selected in the virtual screening were investigated. For the best candidates, the interaction between the ligand and the target active site was investigated (PDB code 6F6S available in the Protein Data Bank) (Berman et al., 2002) via molecular anchoring in order to evaluate the binding energy ( $\Delta \mathrm{G})$, enzyme inhibition constant (Ki) and molecular interactions of ligands with the target protein.

\section{Methodology}

\subsection{Molecule selection and computational calculations}

The structures of 4 drugs (Table 1) that present studies related to inhibition of Ebolavirus infections (Ren; Zhao; Fry; Stuart, 2018) were selected through the DRUGBANK (Wishart et al., 2018) server to serve as a basis for pharmacophore modeling.

The structures were designed in 2D using the free software MarvinSketch 20.7(Csizmadia, 1999) and optimized using the free program ArgusLab (Naz et al., 2009) using the semi-empirical Hamiltonian PM3 (Anders; Koch; Freunscht, 1993) method to obtain the best structural conformation. The HOMO, LUMO orbitals and the electrostatic potential map were calculated for the selected candidates (Braga et al., 2016). 
Table 1. Selected structures with action against ebolavirus to generate a pharmacophoric model.

Drugs Chemical Formula

Source: Own Authorship.

\subsection{Pharmacophore Modeling and Virtual Screening}

After optimization, the files were aligned in Discovery Studio software version 2.1 (Studio, 2008) to obtain similar characteristics and atomic positions, using the crystallographic structure of Benzatropine as a pivot, and sent to the PharmaGist web server (Schneidman-Duhovny et al. al., 2008) to generate at least 3 pharmacophores, which was used to deduce the main structural features through molecular characterization to perform the biological activity (Arooj et al., 2013).

With the pharmacophoric resources generated, the search for coordinates and visualization took place using the Accelrys Discovery Studio software (Studio, 2008), through the Pharmit web server (Koes, 2018) the virtual sorting was performed based on the points through the coordinates, and the max total hits to get the 50 best fit structures.

\subsection{ADMET Predictions}

The properties of Absorption, Distribution, Metabolism and Excretion (ADME) together with the Toxicological ones were performed on the preADMET web server (Lee et al., 2003), through similarity calculations and pharmacokinetic profile of other drugs (Da Silva Costa et al., 2018; Cruz et al., 2018; Vieira et al., 2014). The drugs Bepridil and Paroxetine were used as benchmarks.

The absorption rate by human intestinal absorption (HIA), Cell permeability (PCaco2), Skin permeability (Pskin), 
Cell permeability Maden Darby Canine kidney (PMDCK), Percentage of plasma proteins binding (PPB), Penetration of the blood-brain barrier (Cbrain/Cblood), inhibition of P-Glycoprotein and also mutagenicity and carcinogenicity tests were evaluated, as they are important parameters for evaluating potential new drugs (Rocha et al., 2018; Wadapurkar et al., 2018).

\subsection{Molecular Docking}

The target protein EBOV GP (PDB: 6F6S) (Ren; Zhao; Fry; Stuartet, 2018) was worked on at UCSF Chimera version 1.15 (Pettersen et al., 2004) removing water molecules and other residues that could interfere with the ligand-macromolecule interaction. To validate the active region of the PDB, molecular redocking of the benzatropin ligand complexed to the target protein was performed (Da Silva Costa et al., 2018).

The molecular anchorage calculation was carried out with the help of the free software AutoDock Tools (Morris et al., 2009), where hydrogen was added to the ligands and receptors, performing the partial calculation of gasteiger charges (Gasteiger \& Marsili, 1980). The grid box of size 22x16x28 with spacing of $0.375 \AA$ was defined based on the size of the ligand structures, being centered at the coordinates $\mathrm{X}=-47.084, \mathrm{Y}=11.220$ and $\mathrm{Z}=-3.788$. Such coordinates were obtained through the redocking process close to the MET458 residue of the B chain. The simulation was carried out with the Lamarckian genetic algorithm (Morris et al., 1998), with the ligand considered flexible in relation to the rigid target protein. The other values were assigned by default. The enzymatic complexes obtained from the anchoring process were organized into families according to the RMSD - Root Mean Square Deviation. The best conformations in terms of energies (Bastos et al. 2020) were chosen for the discussion of the results. Hydrophobic interactions and hydrogen bonding were analyzed with the software Discovery Studio and UCSF Chimera.

\subsection{Molecular Dynamics}

The four structures studied in molecular docking were submitted to the later stage of the study using the methodological approach of Rajapaksha et al., (2020) Yang et al., (2020) and Oso et al., (2020).

Conventional molecular dynamics (CMD) simulation was performed through the LARMD server (http://chemyang.ccnu.edu.cn/ccb/server/LARMD/index.php/home/index) (Yang et al., 2020) loading the protein-ligand complex from the molecular docking results. Standard parameters of $4 \mathrm{~ns}$ were used for MD and water time as an explicit model. The simulations were performed by the AMBER16 program using AMBER ff14SB (Maier et al., 2013; Plewczynski et al., 2011) and General AMBER Force Field (GAFF) (Wenthur et al., 2014; Wang \& Merz, 2006) for the ligands and waste. The pdb complexed with the ligands was solvated in a TIP3P water octahedron box (Wold et al., 2018; Price \& Brooks, 2004), for the counter-ions system $\mathrm{Na}+$ or $\mathrm{Cl}$ - were used.

The minimization energy occurred using the SANDER module of the AMBER16 software (Yang, 2015; Case et al., 2005) with 2000 steep descent steps and 3000 conjugate gradient steps, using the PMEMD module (Yang, 2015; Case et al., 2005). In the first stage, the system underwent heating from 10 to $300 \mathrm{~K}$ in $30 \mathrm{~ns}$. Then, the release process similar to minimization took place, the atoms were relaxed at 300K and $1 \mathrm{~atm}$. The Cpptraj module of the AMBER16 program (Roe \& Cheatham, 2013; Case et al., 2005) was used for the analysis of RMSD, Rg and RMSF.

\subsection{Synthetic Route in silico}

The theoretical synthetic route was aided by the investigation of the retro synthesis using the Spaya server (Parrot et al., 2021), its platform results in real synthesis proposals classified through score, where score 1 represents a synthesis $100 \%$ similar to the literature reaction. 


\section{Results and Discussion}

\subsection{Pharmacophore Modeling and Virtual Screening}

After molecular optimization, the pharmacophore model of drug structures was obtained through alignment and evaluation by the PharmaGist server, which presented a score of 4.815. This resulted in 3 pharmacophoric characteristics: an aromatic structure, a hydrogen acceptor and a hydrophobic one (Figure 3). The possible regions where biological interactions can occur between the ligands and the target are described via coordinates according to table 2 .

Figure 3 - Pharmacophoric regions generated by the PharmaGist server.

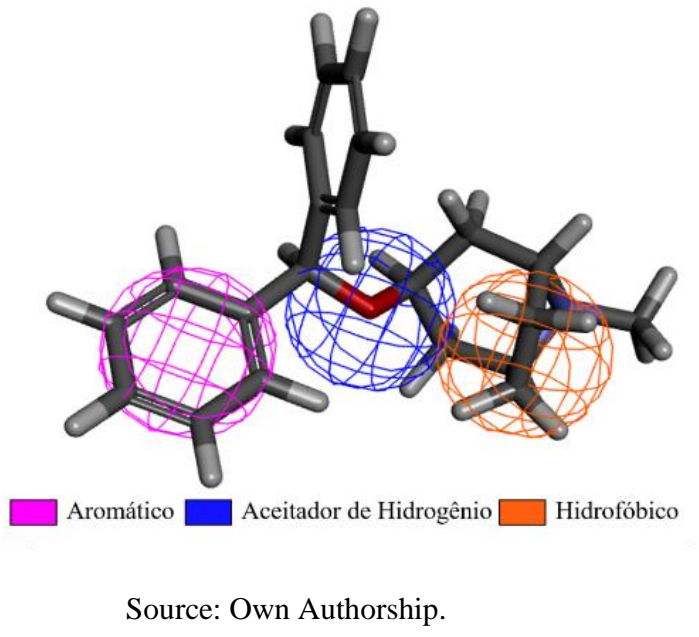

The virtual screening performed by the Pharmit server resulted in the best 50 structures that fit the pharmacophore region, so that after visual analysis, only 25 candidates remained to move on to the next phase of the study.

Table 2. Description of pharmacophoric coordinates.

\begin{tabular}{cccc}
\hline \multirow{2}{*}{ Pharmacophoric Characteristics } & \multicolumn{3}{c}{ Coordinates } \\
\cline { 2 - 4 } & $\mathbf{X}$ & $\mathbf{Y}$ & $\mathbf{Z}$ \\
\hline Hydrogen Acceptor & -40.98 & 16.29 & -7.19 \\
Aromatic & -44.45 & 16.42 & -8.16 \\
Hydrophobic & -37.44 & 16.08 & -6.07 \\
\hline
\end{tabular}

Source: Own Authorship.

\subsection{ADMET Prediction}

The results of the in silico pharmacokinetic predictions were separated into Absorption (Table 3), Distribution (Table 4) and Metabolism (Table 5). Only 5 molecules (ZINC1, ZINC4, ZINC12, ZINC14 and ZINC20) showed favorable characteristics considering the parameters of Percentage of human intestinal absorption (HIA), Cell permeability (PCaco2), Skin permeability (Pskin), Cell permeability Maden Darby Canine kidney (PMDCK), Percentage of plasma proteins binding (PPB), Penetration of the blood-brain barrier (Cbrain/Cblood) and inhibition of P-Glycoprotein, serving as a filter for the others.

Human intestinal absorption (HIA) is of great importance because it acts directly on drug transport in the body, and is also used to predict the oral availability of some drugs (Yan et al., 2008). Molecules that present values lower than 0.4 x 10-6 $\mathrm{cm} / \mathrm{s}$ present low oral absorption. In relation to this parameter, we can classify molecules as malabsorption $(0-20 \%)$, moderate 
Research, Society and Development, v. 11, n. 2, e45311226034, 2022

(CC BY 4.0) | ISSN 2525-3409 | DOI: http://dx.doi.org/10.33448/rsd-v11i2.26034

absorption (20-70\%) and good absorption (70-100\%) (Castillo-Garit et al., 2008). All selected molecules obtained good results in human intestinal absorption (HIA) tests, presenting values above 90\%, with a variation between $93.525 \%$ and $100 \%$ (Table $3)$.

Cell permeability Caco is directly related to the intestinal barrier used to predict drug absorption (Sambuy et al., 2005; Balimane; Chong; Morrison, 2000). Values below $4 \mathrm{~nm} / \mathrm{s}$ indicate low permeability, between 4 and $70 \mathrm{~nm} / \mathrm{s}$ medium permeability and greater than $70 \mathrm{~nm} / \mathrm{s}$ high permeability in relation to PCaco (cell permeability) (Yamashita et al., 2000; Irvine et al., 1999). All molecules showed medium permeability. In relation to PCaco-2, Paroxetine had the highest permeability value of $57.13 \mathrm{~nm} / \mathrm{s}$, and the lowest value was for the ZINC1 molecule with $34.74 \mathrm{~nm} / \mathrm{s}$. The values for permeability in human skin (Pskin) were negative for all molecules, so the administration by application to the skin should not be significant.

Table 3. Absorption parameters of potential EBOV GP inhibitors.

\begin{tabular}{|c|c|c|c|c|}
\hline \multirow{2}{*}{ Molecules } & \multicolumn{4}{|c|}{ Absorption Characteristics } \\
\hline & HIA $(\%)^{\mathrm{a}}$ & PCaco-2 $(\mathrm{nm} / \mathrm{s})^{\mathrm{b}}$ & Pskin $^{\mathrm{c}}$ & $\operatorname{PMDCK}(\mathrm{nm} / \mathrm{s})^{\mathrm{d}}$ \\
\hline ZINC1 & 93.53 & 34.74 & -2.94 & 307.78 \\
\hline ZINC4 & 100.00 & 42.46 & -1.81 & 220.15 \\
\hline $\mathrm{ZINC12}$ & 100.00 & 42.01 & -1.91 & 188.64 \\
\hline ZINC14 & 96.89 & 37.61 & -2.97 & 139.12 \\
\hline ZINC20 & 96.90 & 52.56 & -3.19 & 173.62 \\
\hline Bepridil & 100.00 & 52.27 & -1.97 & 75.22 \\
\hline Paroxetine & 95.88 & 57.13 & -3.89 & 4.56 \\
\hline
\end{tabular}

Note: a) percentage of human intestinal absorption; b) cell permeability (Caco-2); c) skin permeability; d) Madin Darby Canine kidney cell permeability. Source: Own Authorship.

According to Irvine et al., (1999) the MDCK cell system can be used as a tool for rapid screening for permeability. Values below $100 \mathrm{~nm} / \mathrm{s}$ are considered to have low permeability (Dezani et al., 2016). All screened molecules showed high permeability ZINC1 $(307.78 \mathrm{~nm} / \mathrm{s})$, ZINC4 $(220.15 \mathrm{~nm} / \mathrm{s})$, ZINC12 $(188.64 \mathrm{~nm} / \mathrm{s})$, ZINC20 $(173.62 \mathrm{~nm} / \mathrm{s})$ and ZINC14 $(139.12 \mathrm{~nm} / \mathrm{s})$, while the drugs Bepridil and paroxetine showed low permeability of the MDCK cellular system.

Table 4 shows the distribution of properties in percentage of Plasma Protein Binding - PPB and P-glycoprotein, the main contributors to the evaluation of drug distribution properties. Binding to plasma proteins is one of the mechanisms for the drug to be distributed in the human body via the bloodstream, providing a better therapeutic effect (Moda, 2007). PPB values (>70\%) show significant protein binding (Benet \& Hoener, 2002). The molecules ZINC1, ZINC4, ZINC12 and ZINC20 showed values of $82.54 \%, 92.41 \%, 81.01 \%$ and $71.37 \%$, respectively. Such values are similar to those obtained by the drugs Bepridil (85.71\%) and Paroxetine (82.77\%). Only the ZINC14 molecule is weakly bound.

The blood-brain barrier (BBB) is related to the blood-brain interface that maintains the balance of the central nervous system (CNS), circumscribes the introduction of drug administration (Mendonça, 2016). Compounds with BBB values lower than -1 present poor distribution to the brain, whereas BBB values greater than 1 have an easy crossover and present Central Nervous System activity (Ma; Chen; Yang, 2005). For values related to BBB, the structure of the molecule ZINC14 (0.88) and ZINC1 (0.69) present the best values among the 5 candidates, approaching the reference drug Paroxetine (0.27). The molecules ZINC4 (2.18), ZINC12 (2.15), ZINC20 (1.18) showed values greater than 1, characterizing a high probability of penetration (Mendonça, 2016). The drug Bepridil obtained a high value of 5.99 in relation to penetration of the blood-brain barrier. 
Table 4. Distribution properties in percentage of PPB, penetration of the blood-brain barrier (BBB) and P-glycoprotein inhibition of potential EBOV GP inhibitors.

\begin{tabular}{|c|c|c|c|}
\hline \multirow{2}{*}{ Molecules } & \multicolumn{3}{|c|}{ Distribution Characteristics } \\
\hline & PPB $(\%)^{\mathbf{a}}$ & $\mathbf{B B B}^{\mathbf{b}}$ & P-Glycoprotein (Inhibition) $^{\mathrm{c}}$ \\
\hline ZINC1 & 82.54 & 0.69 & Non \\
\hline ZINC4 & 92.41 & 2.18 & Non \\
\hline ZINC12 & 81.01 & 2.15 & Non \\
\hline ZINC14 & 64.42 & 0.88 & Non \\
\hline ZINC20 & 71.37 & 1.18 & Non \\
\hline Bepridil & 85.71 & 5.99 & Non \\
\hline Paroxetine & 82.77 & 0.27 & Non \\
\hline
\end{tabular}

Note: a) percentage of binding to plasma proteins; b) penetration of the blood-brain barrier (Blood-Brain Barrier- BBB); c) Inhibition of P-Glycoprotein. Source: Own Authorship.

The P-glycoprotein indicates a defense against chemical agents that are not usual in the body (Azeredo; Uchôa; Costa, 2009) increasing the resistance of cells (Reeve, 2014). No molecule showed inhibition of P-glycoprotein activity.

The CYP450 enzymes (CYPs) are related to xenobiotic compounds that support the induction of more than one CYP450 gene family. The liver is the organ where CYP450 plays an important role, as it is where it is active in the catalysis of biotransformation related to xenobiotics (Ortiz et al., 2012; Orellana \& Guajardo, 2004). All screened molecules showed inhibition of cytochrome P450 2C19 enzymes, but drugs did not show inhibition, drugs and molecules inhibited cytochrome P450 2C9 (Table 5).

Table 5. Metabolic properties of potential EBOV GP inhibitors.

\begin{tabular}{|c|c|c|c|c|c|c|}
\hline \multirow[b]{2}{*}{ Molecules } & \multicolumn{6}{|c|}{ Metabolism } \\
\hline & 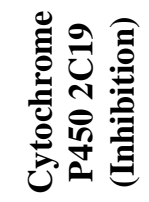 & 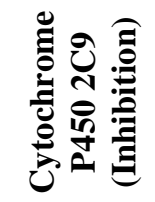 & 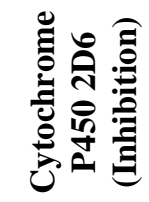 & 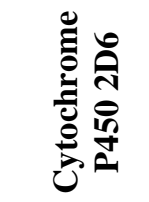 & 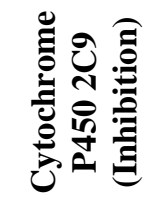 & 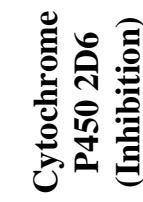 \\
\hline ZINC1 & Inhibitor & Inhibitor & Non & Non & Inhibitor & Weakly \\
\hline ZINC4 & Inhibitor & Inhibitor & Non & Non & Inhibitor & Weakly \\
\hline ZINC12 & Inhibitor & Inhibitor & Non & Weakly & Inhibitor & Weakly \\
\hline ZINC14 & Inhibitor & Inhibitor & Non & Non & Inhibitor & Weakly \\
\hline ZINC20 & Inhibitor & Inhibitor & Non & Weakly & Inhibitor & Weakly \\
\hline Bepridil & Non & Inhibitor & Inhibitor & Substrate & Non & Substrate \\
\hline Paroxetine & Non & Inhibitor & Inhibitor & Substrate & Non & Weakly \\
\hline
\end{tabular}

Source: Own Authorship.

The CYP2C19, 2D6 and 3A4 are responsible for occupying 70\% of CYP450 (Ortiz et al., 2012). In cytochrome P450 2 D6 only the drugs showed inhibition and action on the substrate. Cytochrome 2C9, 2D6, 3A4 are part of the family responsible for metabolizing different drugs in a living organism (Ortiz et al., 2012). All selected molecules showed inhibition of cytochrome P450 3A4 enzymes. Cytochrome P450 enzymes metabolize most drugs used in the abrogation of neoplasms or malignant cells (Marcolin et al., 2004).

The Ames test consists of using standardized cultures of Salmonella typhimurium, functioning as a drug receptor to cause distinct mutations. This test is used to analyze the mutagenicity of drugs, being one of the most prescribed by world entities (Santos, 2007). Table 6 presents the data related to mutagenicity, carcinogenic effects in rats and mice. All molecules showed mutagenicity in relation to the Ames test. In the specific tests through the TA 100 and TA 1535 strains analyzed, the 
effectiveness or non-efficacy of the molecules in relation to mutagenicity can be verified.

Table 6. Toxicological properties of potential EBOV GP inhibitors.

\begin{tabular}{|c|c|c|c|c|c|c|c|}
\hline \multirow[b]{2}{*}{ Molecules } & \multicolumn{5}{|c|}{ Mutagenicity } & \multicolumn{2}{|c|}{ Carcinogenicity } \\
\hline & 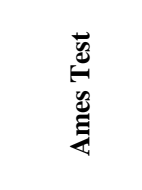 & 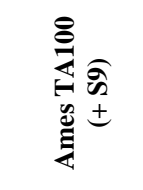 & 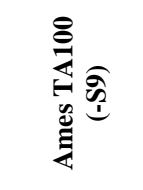 & 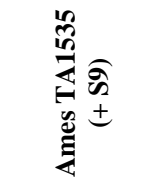 & 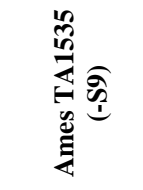 & 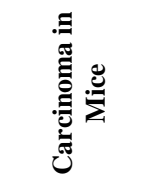 & 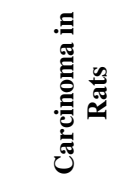 \\
\hline ZINC1 & Mutagen & Positive & Positive & Positive & Positive & Negative & Positive \\
\hline ZINC4 & Mutagen & Positive & Positive & Positive & Positive & Positive & Positive \\
\hline ZINC12 & Mutagen & Positive & Positive & Positive & Positive & Positive & Positive \\
\hline ZINC14 & Mutagen & Positive & Positive & Positive & Positive & Positive & Positive \\
\hline ZINC20 & Mutagen & Positive & Positive & Positive & Positive & Negative & Positive \\
\hline Bepridil & Mutagen & Negative & Negative & Positive & Negative & Negative & Positive \\
\hline Paroxetine & Mutagen & Negative & Negative & Negative & Negative & Negative & Negative \\
\hline
\end{tabular}

Source: Own Authorship.

For the TA $100(+$ S9) and (-S9) tests, all molecules showed positive results, except for Bepridil and Paroxetine, which showed negative values. In the Ames TA 1535 (+S9) tests, only Paroxetine was negative. In the TA 1535 (-S9) tests, only the drugs showed negative values. In the carcinogenicity test in mice, the molecule ZINC1 and ZINC20 showed negative parameters according to the reference drugs, for carcinogenicity in rats, only the drug Paroxetine showed a negative value.

The Table 7 presents the results regarding drug classification. Among the screened molecules, only ZINC14 showed violation of the Lead-Like rule, all showed violation of the MDDR-Like rule because they did not present aromatic rings and rotating bridges. Only ZINC1 showed violation of the WDI-Like rule.

The drugs Bepridil and Paroxetine showed more violations in total compared to the investigated molecules, thus demonstrating that even drugs on the market have aspects that violate the standards.

Table 7. Drug-like properties of potential EBOV GP inhibitors.

\begin{tabular}{|c|c|c|c|c|c|c|c|c|c|c|}
\hline \multirow[b]{3}{*}{ Molecules } & \multicolumn{10}{|c|}{ Drug Similarities } \\
\hline & \multicolumn{2}{|c|}{$\begin{array}{c}\text { CMC- } \\
\text { Like Rule }\end{array}$} & \multicolumn{2}{|c|}{ Lead-Like Rule } & \multicolumn{2}{|c|}{$\begin{array}{l}\text { MDDR- } \\
\text { Like Rule }\end{array}$} & \multicolumn{2}{|c|}{ Lipinski's rule } & \multicolumn{2}{|c|}{ WDI-Like Rule } \\
\hline & 里 & 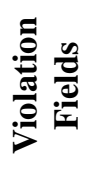 & & 总 & 参 & 疍 & & 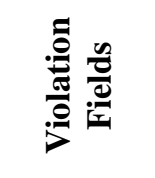 & 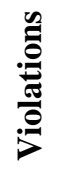 & 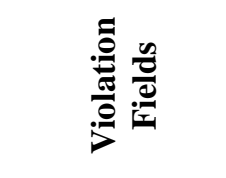 \\
\hline ZINC1 & - & - & - & - & 2 & $\mathrm{~b} / \mathrm{c}$ & - & - & 1 & Kier_alpha_03 \\
\hline ZINC4 & - & - & - & - & 2 & $\mathrm{~b} / \mathrm{c}$ & - & - & - & $\begin{array}{ll}-1 & - \\
- & \end{array}$ \\
\hline ZINC12 & - & - & - & - & 2 & $\mathrm{~b} / \mathrm{c}$ & - & - & - & - \\
\hline ZINC14 & - & - & 1 & AlopP98 & 2 & $\mathrm{~b} / \mathrm{c}$ & - & - & - & - \\
\hline ZINC20 & - & - & - & - & 2 & $\mathrm{~b} / \mathrm{c}$ & - & - & - & - \\
\hline Bepridil & - & - & 2 & a/AlopP98 & - & - & 1 & AlopP98 & 2 & $\begin{array}{c}\text { AlopP9, } \\
\text { Kier_alpha_03 }\end{array}$ \\
\hline Paroxetine & - & - & 1 & AlopP98 & 1 & $\mathrm{c}$ & - & - & - & $\begin{array}{r}-1 \\
- \\
-\end{array}$ \\
\hline
\end{tabular}

Note: $\mathrm{a}=$ Molecular Weight, $\mathrm{b}=$ No rings, $\mathrm{c}=$ No rotating connections. Source: Own Authorship. 


\subsection{Computer Calculations}

Molecular orbitals have important characteristics for biological systems, such as orbital density, charge and volume, as they directly influence the ability of the ligand to interact with the enzymatic active site (Pereira et al., 2016). The HOMO and LUMO boundary molecular orbitals of each of the structures can be seen in Figure 4. The HOMO orbital of the ZINC1 structure is balanced in almost all molecules, only the sulfur atom of the tetrahydrothiophene fragment and the oxygen of oxacyclopentane did not present orbitals. The LUMO for this molecule has a higher density in the region of the nitrogen double bond. ZINC4 features the HOMO and LUMO on the tetrahydrothiophene fragment on opposite sides of the structure. For the ZINC12 molecule, the HOMO is concentrated towards the oxacyclopentane fragment with the exception of the hydrogen atom, but the LUMO has a higher density in the center of the molecule in the nitrogen double bond. The ZINC14 molecule concentrates the HOMO orbital in the aromatic ring and in the central oxygen atom, while the LUMO is in the opposite region on the $\mathrm{N}=\mathrm{C}-\mathrm{O}$ bonds of the oxadiazole fragment. The HOMO of the ZINC20 molecule is concentrated in the pyridine ring and in the nearby oxygen, while the LUMO is present in the double bond of oxygen with oxacyclopentane. The HOMO orbital has electron donating properties while the LUMO acts as an electron acceptor indicating a favorable region for interaction with biological systems (Ouakki et al., 2019).

Figure 4 - Frontier Orbital HOMO and LUMO for selected structures.

\section{LUMO}

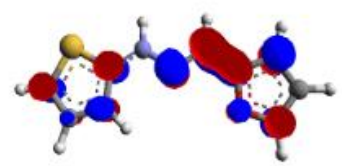

ZINC1

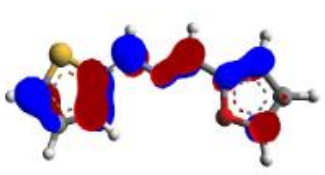

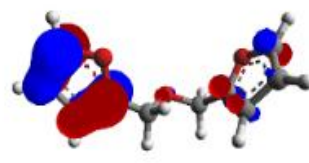

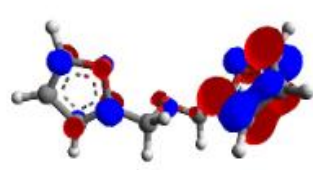

ZINC4

ZINC12

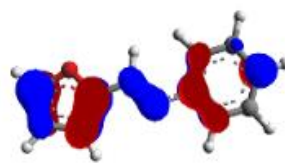

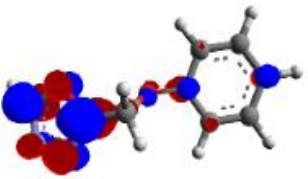

ZINC14

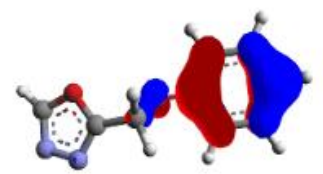

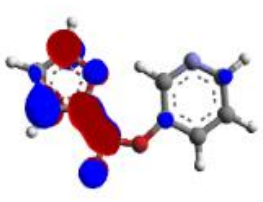

ZINC20

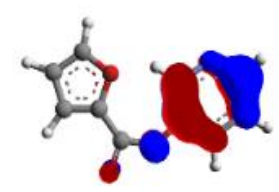

HOMO

Source: Own Authorship.

Electronic parameters are important for the ligand-protein interaction. The most electronegative regions present a region with the highest concentration of electrons in the molecule (Braga; Corpe; Marinho; Marinho, 2016) demonstrating the area with the highest probability of electrophilic attack by organic particles (Ramalingam et al., 2011). The electrostatic potential maps of each selected molecule are shown in Figure 5. 
Figure 5 - Electrostatic potential maps of selected molecules, a) ZINC1, b) ZINC4, c) ZINC12, d) ZINC14 e) ZINC20.

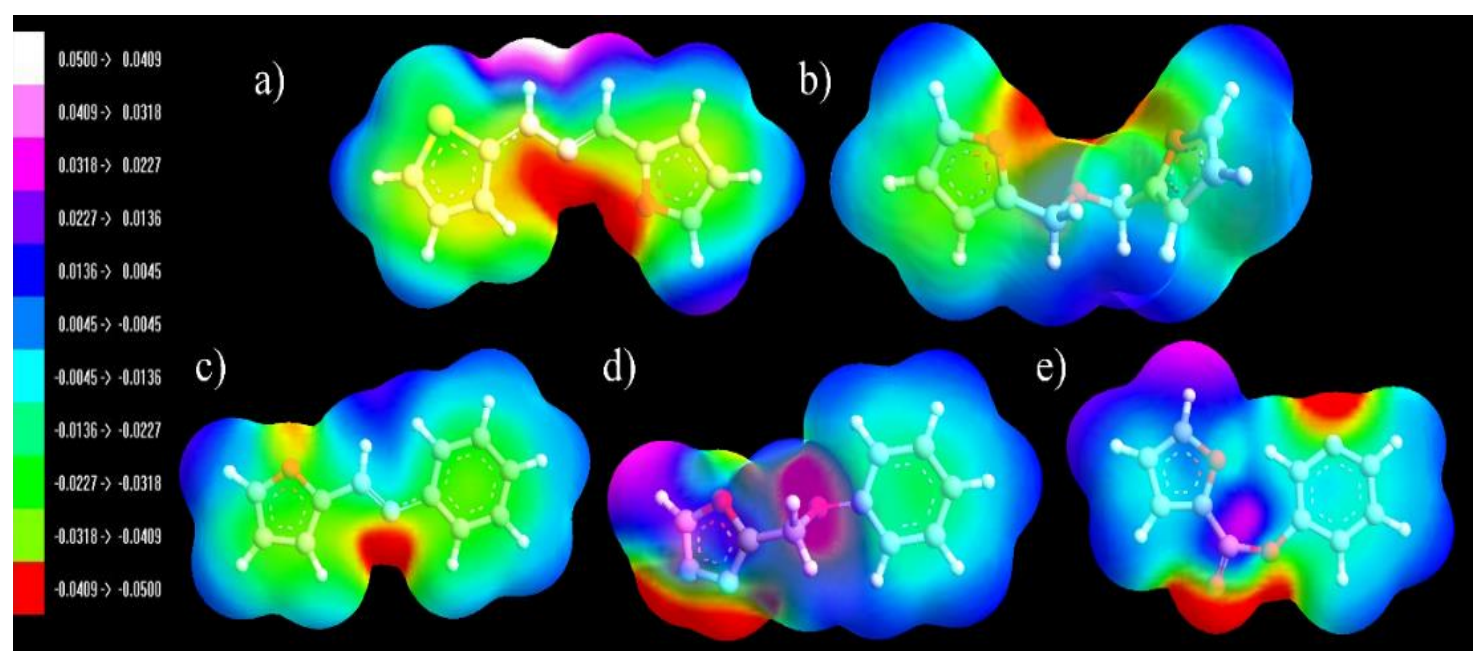

Source: Own Authorship.

\subsection{Validation and Molecular Docking}

The validation of the active site and the molecular anchoring process occurred through the evaluation of the Root Mean Square Deviation (RMSD) between the crystallographic benzantropine ligand with the pose obtained from the computational ligand. Figure 6 demonstrates the overlap of both ligands, which presented a result of $1.8232 \AA$, to be considered satisfactory, the RMSD must present a result of 2 Å or less (Ramírez \& Caballero, 2018).

Figure 6 - Comparison of the crystallographic ligand alignment (in green) with the position obtained in the redocking (in red).

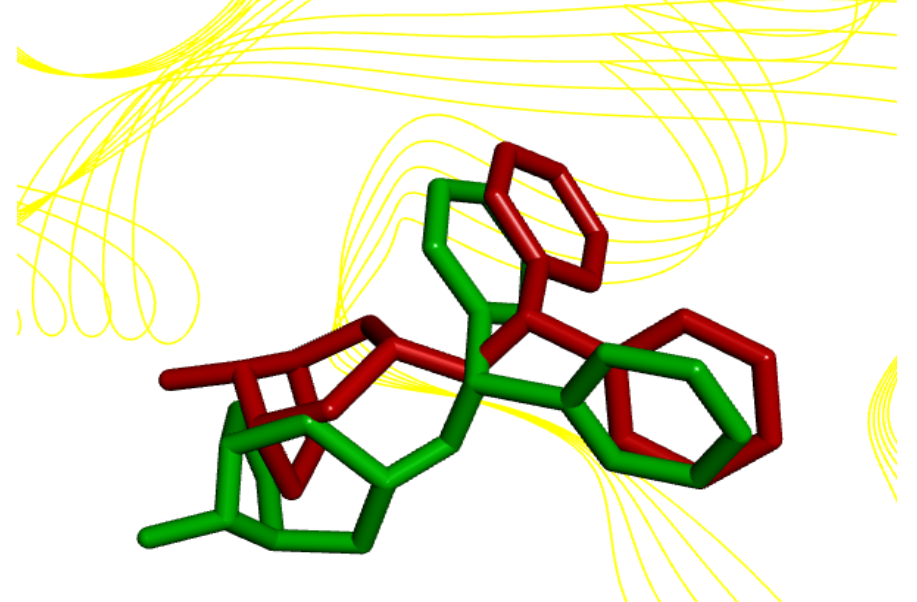

Source: Own Authorship.

In addition to the result of the 5 molecules, the docking of the drugs Bepridil and Paroxetine was also observed, thus allowing to verify and compare the binding energies of the selected molecules with the commercial drugs. The binding energy can be observed in Figure 7. 
Figure 7 - Results of the binding energy of molecules with the Ebolavirus glycoprotein.

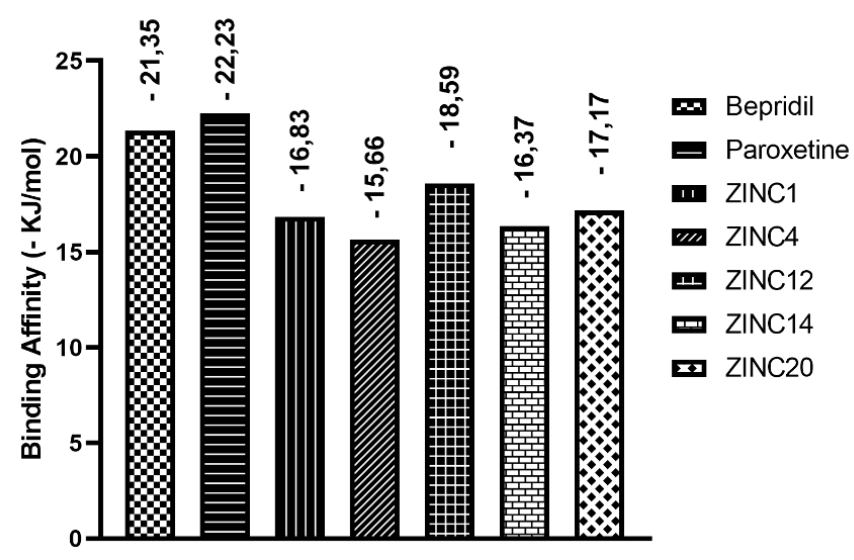

Source: Own Authorship.

The drug Bepridil had a binding energy of $-21.35 \mathrm{KJ}_{\mathrm{mol}}{ }^{-1}$ and the drug Paroxetine a binding energy of -22.23 $\mathrm{KJ}_{\mathrm{mol}}{ }^{-1}$. This type of energy occurs when a ligand-protein complex is formed, they are characteristics for analyzing the ease of protein-ligand interaction, the lower the energy value, the more likely a binding to occur (Souza, 2015; Gujjula, 2008). The selected structures, despite not having better binding energies than the comparison drugs, have favorable energy for an interaction to occur, as the binding energy score usually occurs between -7 to $-10 \mathrm{KJ} / \mathrm{mol}$ (Azam \& Abbasi, 2013; Bissantz et al., 2000).

The ZINC12 molecule showed the best binding energy with a value of $-18.59 \mathrm{KJ} . \mathrm{mol}^{-1}$ and an inhibition constant equal to $555.9 \mu \mathrm{M}$. No hydrogen bonds were observed for this molecule, but it showed 12 hydrophobic interactions between the ligand and the target protein. The amino acid MET548 performed a pi-sulfur interaction, the stacked pi-pi interaction occurred with the amino acid TYR517, LEU515 performed a pi-sigma type interaction, the pi-alkyl interactions occurred with residues ALA101, LEU184, LEU43, LEU554, LEU558, VAL66, residues ILE38, ILE555 and LEU186 performed van der Waals interactions (Figure 8).

Figure 8 - Molecular docking of the ZINC12 ligand with the EBOV GP. A) 2D representation of the active region of the enzyme; B) 3D representation.

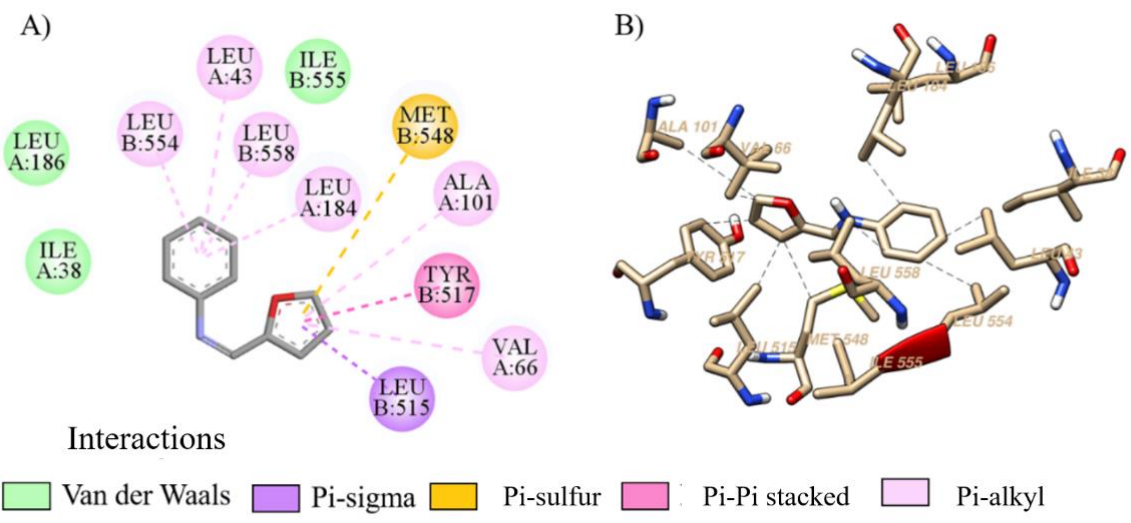

Source: Own Authorship. 
The ZINC20 molecule did not form a hydrogen bond with the EBOV GP receptor. The molecular interactions that occurred were of the pi-alkyl and alkyl type at amino acids ILE38, LEU184, LEU43, LEU515, LEU554, LEU558, MET548, TYR517, VAL66 (Figure 9). Affinity parameters for ZINC20 molecule were 989.31 $\mu \mathrm{M}$ for inhibition constant and binding energy of $-17.17 \mathrm{KJ} \cdot \mathrm{mol}^{-1}$.

Figure 9 - Molecular docking of the ZINC20 ligand with the EBOV GP. A) 2D representation of the active region of the enzyme; B) 3D representation.

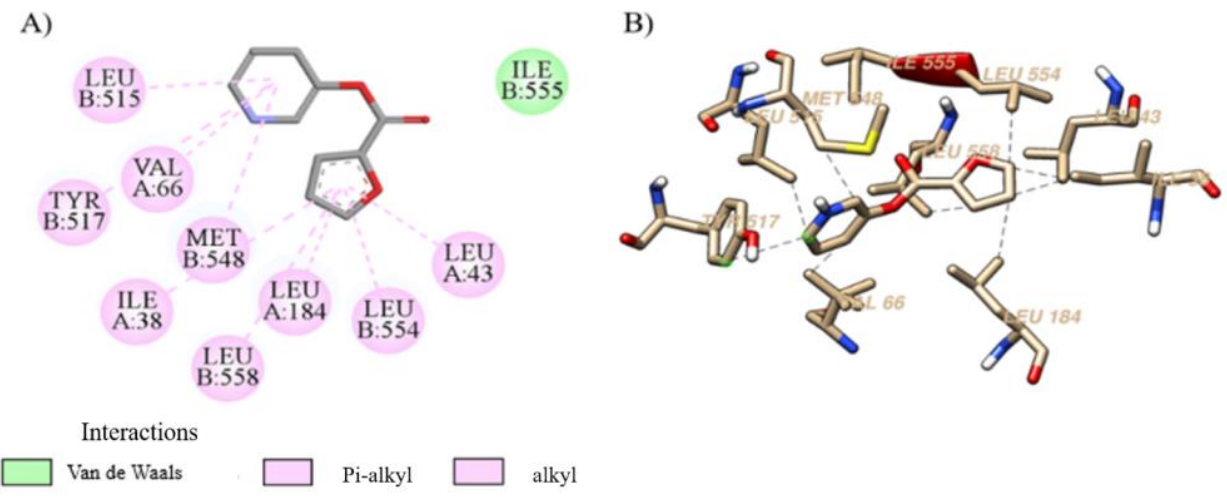

Source: Own Authorship.

The inhibition constant presented for ZINC1 was $1140 \mu \mathrm{M}$ and a binding energy of $-16.83 \mathrm{KJ}^{\mathrm{mol}}{ }^{-1}$, interacting with 10 hydrophobic residues in the active site region. The MET548 residue performed a pi-enxofre type interaction, LEU515 and LEU554 pi-sigma type interactions, as pi-alkyl interactions occurred in the amino acids ALA101, LEU184, LEU43, LEU558, VAL66 (Figure 10). The MET548 residue formed a hydrogen bond with a distance of $4.81 \AA$, a region where the HOMO and LUMO orbits of this molecule are concentrated with the highest electrostatic potential. Hydrogen bonds are stronger than hydrophobic interactions and are of great importance for biological interactions. The drug ligations cannot be as strong as covalent and ionic, they need to be absorbed and subsequently eliminated by the human body (Barreiro \& Fraga, 2014).

Figure 10 - Molecular docking of the ZINC1 ligand with the EBOV GP. A) 2D representation of the active region of the enzyme; B) 3D representation.

$$
\text { A) } \text { ILE }
$$

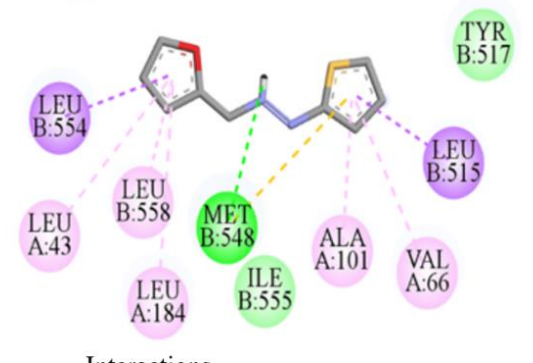

Interactions

$\square$ Van de Waals

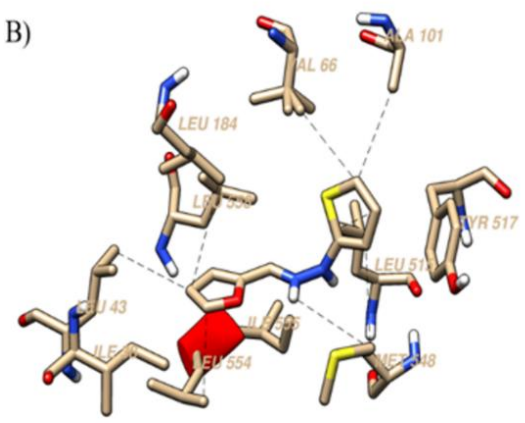

Source: Own Authorship. 
The chemical interactions of the ZINC14 ligand as alvo will consist of a pi-enxofre interaction with the amino acid MET548 and pi-alkyl with the residues LEU554 and LEU558 (Figure 11). In addition to these, interactions with 10 hydrophobic residues occur and the formation of a hydrogen bond with a distance of $5.34 \AA$ as the amino acid ILE185 in the oxadiazole region where it presents the LUMO orbital and the most electronegative area with no potential map. The binding energy obtained in the interaction of this ligand with the EBOV GP receptor was $-16.37 \mathrm{KJ} . \mathrm{mol}^{-1}$ and an inhibition constant of $1350 \mu \mathrm{M}$.

Figure 11 - Molecular docking of the ZINC14 ligand with the EBOV GP. A) 2D representation of the active region of the enzyme; B) 3D representation.

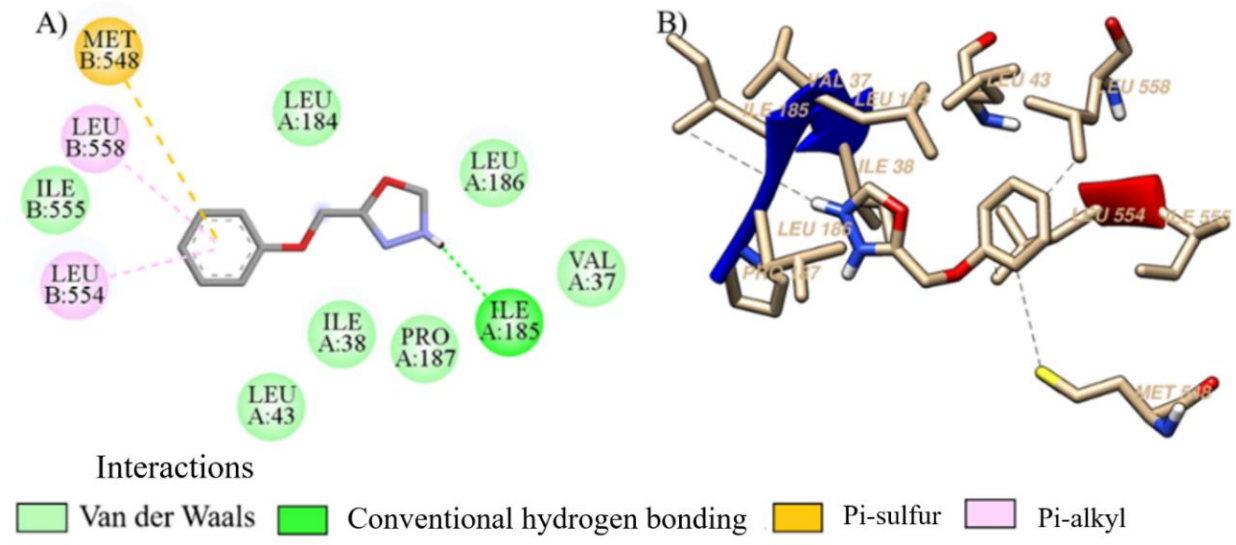

Source: Own Authorship.

The ZINC4 molecule presented the highest inhibition constant equal to $1820 \mu \mathrm{M}$, however it was the structure with the lowest binding energy of $-15.66 \mathrm{KJ}_{\mathrm{mol}}{ }^{-1}$, with 9 hydrophobic interactions and forming a hydrogen bond with the amino acid LEU554 with distance $4.40 \AA$ A. The TYR517 residue performed a stacked pi-pi interaction, MET548 presented a pi-sulfur interaction, the amino acids LEU184, LEU43, LEU515, LEU558 and VAL66 showed pi-alkyl interactions (Figure 12).

Figure 12 - Molecular docking of the ZINC14 ligand with the EBOV GP. A) 2D representation of the active region of the enzyme; B) 3D representation.

A)

ILE

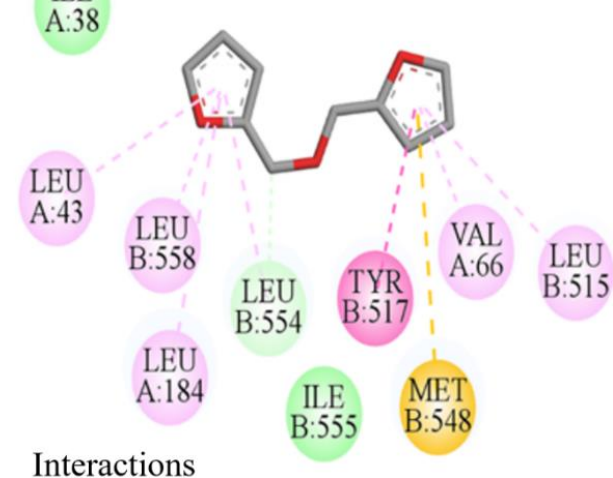

Van der Waals

Hydrogen carbon bond

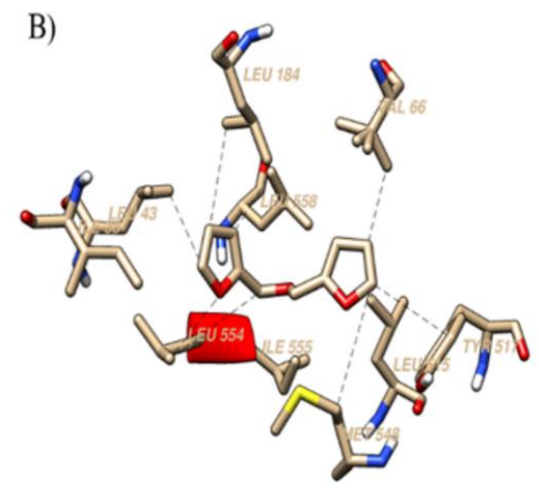

Pi-sulfur

Pi-Pi stacked

Pi-alkyl

Source: Own Authorship. 
The results presented in the next few years obtained by Mali e Chaudhari (2019), where the Ebola virus glycoprotein was also studied and obtained $\Delta \mathrm{G}$ values that varied from $-20.48 \mathrm{KJ} \mathrm{mol}^{-1}$ to $-14.20 \mathrm{KJ}$. mol ${ }^{-1}$. The hydrogen bonds occur in the expected regions in the calculations of HOMO, LUMO and more electronegative areas showing the biological interactions as ligands.

\subsection{Molecular Dynamics}

To evaluate the conformational stability of the receptor-ligand complex, 4 ns molecular dynamics simulations were applied to the EBOV GP receptor and the ligands ZINC01, ZINC04, ZINC12, ZINC14 and ZINC20, observing the conformational changes and binding affinities. the main characteristics of ligands that affect conformation can be observed in the high fluctuations in root mean square deviation (RMSD) and root mean square fluctuation (RMSF) (Mukund et al., 2019).

In figure 13 we can see how the different ligands indicate variations in fluctuations, thus verifying that they have a critical role in the process of conformation movement. The structures of ZINC20 and ZINC04 have a lower RMSD value compared to the others, which can confirm that the structure of EBOV GP is more stable with these ligands.

Figure 13 - Mean squared deviation (RMSD) plot across molecular dynamics (MD) simulations. In all Figures, the RMSD plot of the EBOV GP receptor was represented by the black color, while the RMSD of the ligands was represented in different colors. A) ZINC01 with red color, B) ZINC02 with blue color, C) ZINC12 with green color, D) ZINC14 with pink color and E) ZINC20 with orange color.
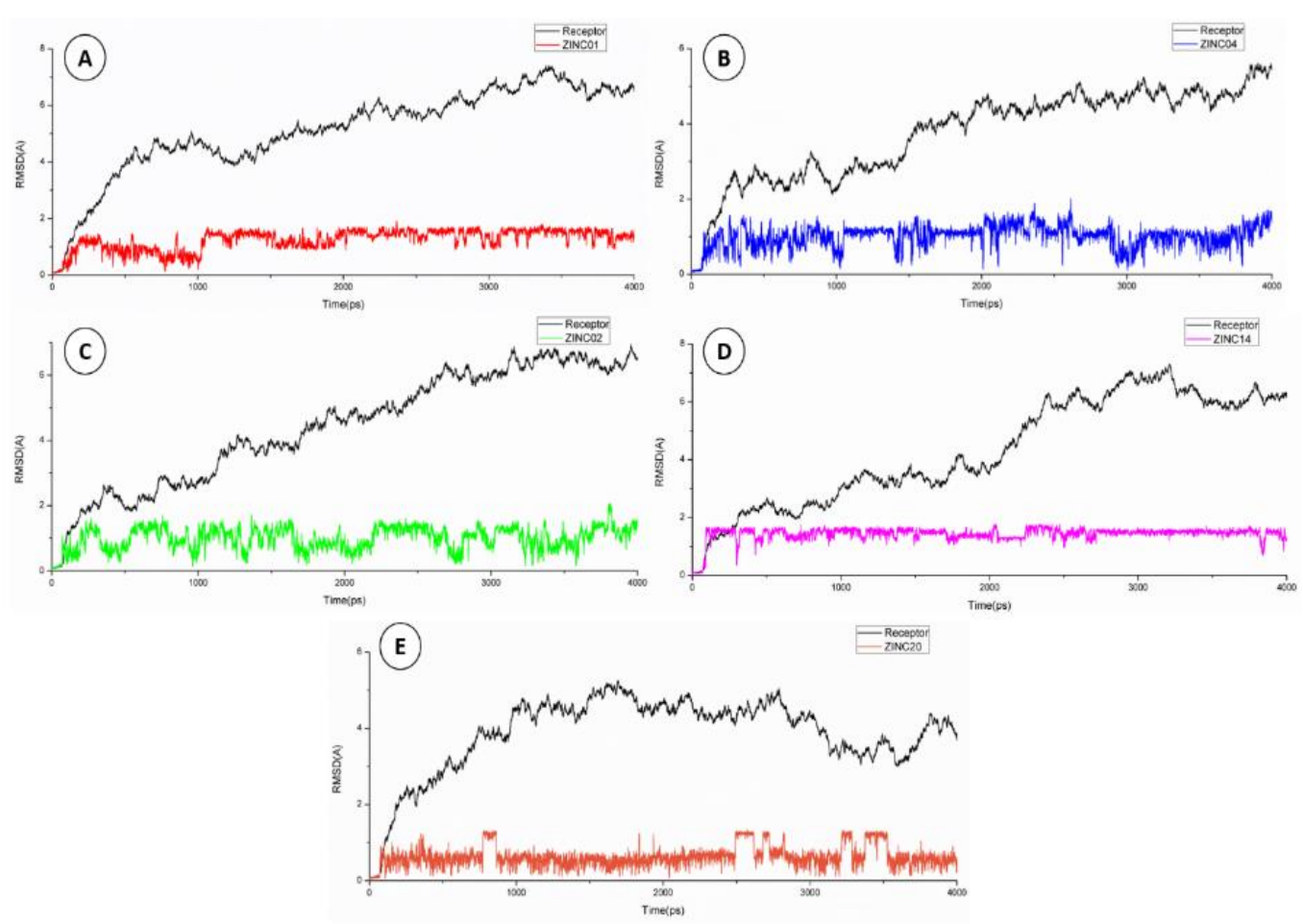

Source: Own Authorship.

The ZINC14 ligand showed little conformational fluctuation, obtaining its stability from 2500 ps, while the ZINC20 ligand presents some fluctuation peaks, its greater stability occurs between 1000 and 2500 ps, the others present large variations in their stabilities. 
The by residue, Root Mean Square Fluctuations (RMSF) (Figure 14) showed fluctuation between 10 and $60 \AA$, we can observe that the ligand ZINC20 was the one that presented the lowest values of fluctuation, but still being close to the others as shown in the figure 14.

Figure 14 - Mean square fluctuation plot (RMSF) for all molecular dynamics complexes.

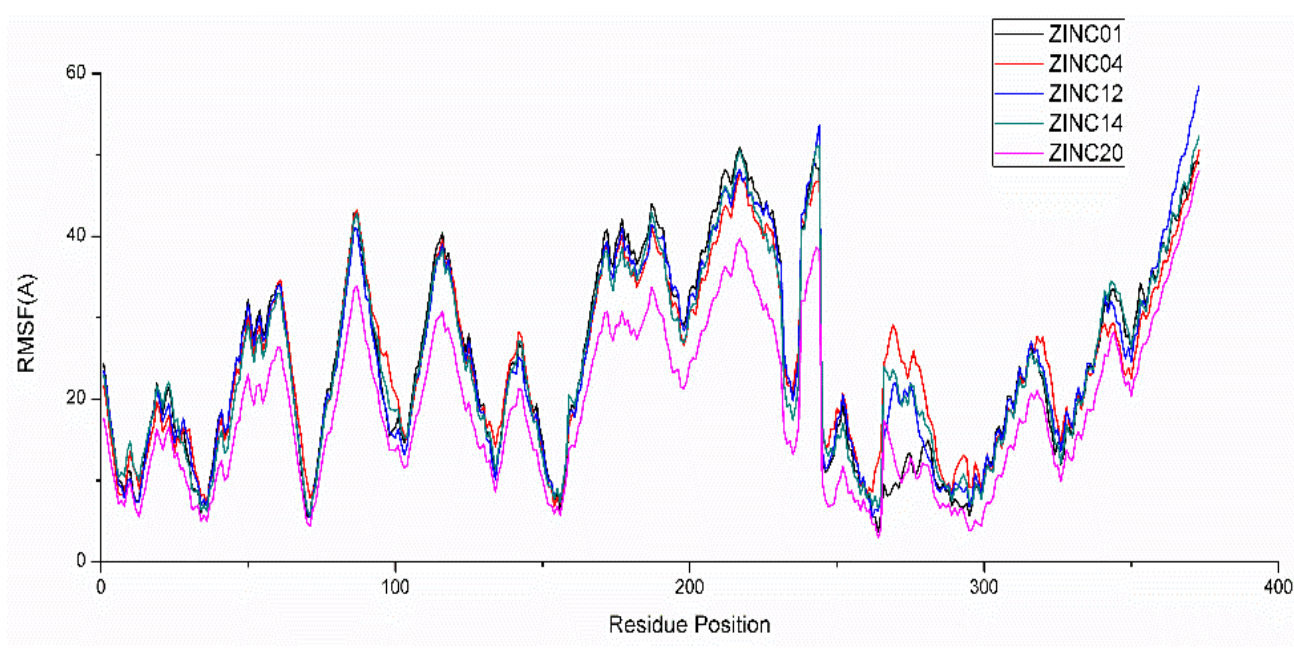

Source: Own Authorship.

The binding free energies obtained in molecular dynamics by means of MM/PB (GB) corroborate the prediction of molecular docking. EBOV GP presented the highest value of $\Delta$ GB for ZINC20 $(-5.82 \mathrm{kcal} / \mathrm{mol})$ and $\Delta \mathrm{PB}=-4.88 \mathrm{kcal} / \mathrm{mol}$, the ligand ZINC14 presented results of $\Delta \mathrm{GB}=-5.79 \mathrm{kcal} / \mathrm{mol}$ and $\Delta \mathrm{PB}=-3.57 \mathrm{kcal} / \mathrm{mol}$, for ZINC12 it was $\Delta \mathrm{GB}=-5.63$ $\mathrm{kcal} / \mathrm{mol}$ and $\Delta \mathrm{PB}=-4.11 \mathrm{kcal} / \mathrm{mol}, \mathrm{ZINC} 04 \mathrm{resulted}$ in $\Delta \mathrm{GB}=-3.47 \mathrm{kcal} / \mathrm{mol}$ and $\Delta \mathrm{PB}=-2.91 \mathrm{kcal} / \mathrm{mol}$ and the ligand ZINC01 obtained results of $\Delta \mathrm{GB}=-4.22 \mathrm{kcal} / \mathrm{mol}$ and $\Delta \mathrm{PB}=-2.51 \mathrm{kcal} / \mathrm{mol}$ (table 8$)$. Such energies demonstrate that ligands have a favorable tendency to bind to the receptor, even with fluctuations interactions with the active region are not impaired.

Table 8. Ligands and their binding free energy.

\begin{tabular}{cccccccccc}
\hline Compound & ELE & VDW & GAS & PBSOL & PBTOT & GBSOL & TS & $\Delta$ PB & $\Delta$ GB \\
\hline ZINC01 & -2.76 & -22.83 & -25.59 & 6.30 & -19.30 & 4.58 & 16.79 & -2.51 & -4.22 \\
ZINC04 & -1.64 & -18.65 & -20.29 & 4.87 & -15.43 & 4.30 & 12.52 & -2.91 & -3.47 \\
ZINC12 & -0.99 & -20.38 & -21.37 & 3.81 & -17.56 & 2.29 & 13.45 & -4.11 & -5.63 \\
ZINC14 & -3.19 & -23.80 & -26.99 & 6.94 & -20.05 & 4.72 & 16.48 & -3.57 & -5.79 \\
ZINC20 & -3.72 & -25.48 & -29.20 & 7.35 & -21.85 & 6.41 & 16.97 & -4.88 & -5.82 \\
\hline
\end{tabular}

Note: Electrostatic energy (ELE), van der Waals contribution (VDW), total gas phase energy (GAS), non-polar and polar contributions to solvation (PBSOL / GBSOL), Final estimated binding free energy (deltaPB / deltaGB) calculated from the above terms (PBTOT / GBTOT) and entropy (TS), their unit is kcal / mol. Source: Own Authorship.

It is noticeable that the contributions of van der walls (VDW) and the total energies of the gas phase (GAS) were the ones that contributed the most to the interaction energy of the ligands with the receptor, whereas the entropy energies were the ones that contributed the least to the binding free energy result. ZINC20 showed the highest number of hydrogen bonds during

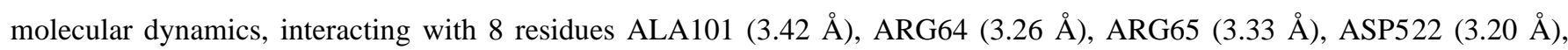

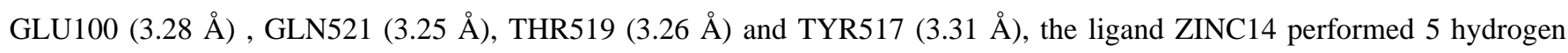

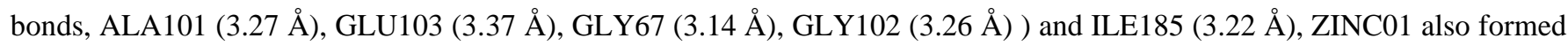

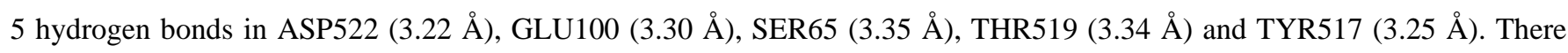


were 3 hydrogen bonds for the ligand ZINC04 with residues ARG64 (3.37 $)$ ), GLN521 (3.23 $⿱$ ) and THR519 (3.26 $)$ ), ZINC12 also showed only 3 hydrogen interactions in ARG64 (3.17 ̊̊), THR519 (3.15 $)$ ) and TYR517 (3.26 ^).

The molecular dynamics results confirm the binding free energy and the tendency of these ligands to bind with the EBOV GP receptor, demonstrating that they are potential targets for future investigations.

\subsection{Synthetic Route in silico}

The ZINC1 showed a score of 0.8 in the retrosynthesis obtained from the SPAYA server, the theoretical synthesis of the compound (Figure 15) starts with the production of forfural (I), it can be obtained from the dehydration of xylose (Mamman et al., 2008; Zeitsch, 2000), may also occur by the putative mechanism for the acid-catalyzed dehydration of xylose, in which displacement of the protonated C-2 hydroxyl group leads to a 2,5-anhydride intermediate which dehydrates to furfural (Nimlos et al., 2006; Antal Jr et al., 1991). Subsequently, it is necessary to obtain the compound 1,3-thiazolidin-2-ylhydrazine (II) from 1,3-thiazol-2-amine following the reaction observed in Singh et al., (2005). The ZINC1 molecule can be obtained in step III with the reaction of forfurral (I) with 1,3-thiazolidin-2-ylhydrazine (II) through the open vessel process and cooling during the heating of the synthesis (La Regina et al., 2011).

Figure 15 - Theoretical route to obtain the ZINC1 compound.

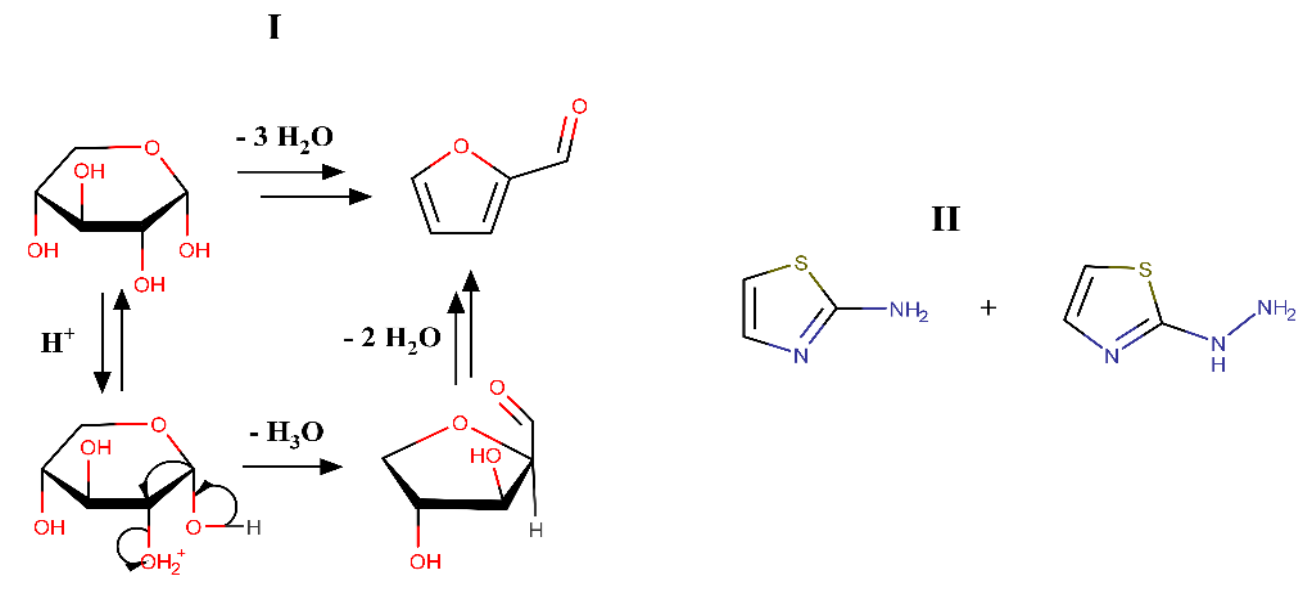

III

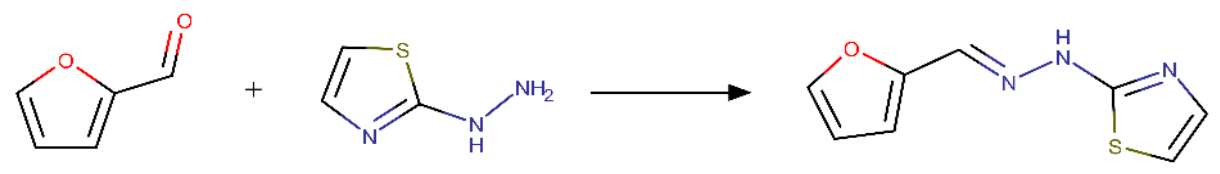

Source: Own Authorship.

The retrosynthesis score of the ZINC4 compound was 1 and can be seen in figure 16, the first step of the synthetic route consists of obtaining 2-(Bromomethyl)furan (I) from the methodological procedure patented by Beaulieu \& Ohemeng, (1999). In sequence, the synthesis of the compound ZINC4 (II) is carried out by mixing phenol with 2-(Bromomethyl)furan (I), a process already known in the literature (Annales de chimie 1942). 
Figure 16 - Theoretical route to obtain the ZINC4 compound.

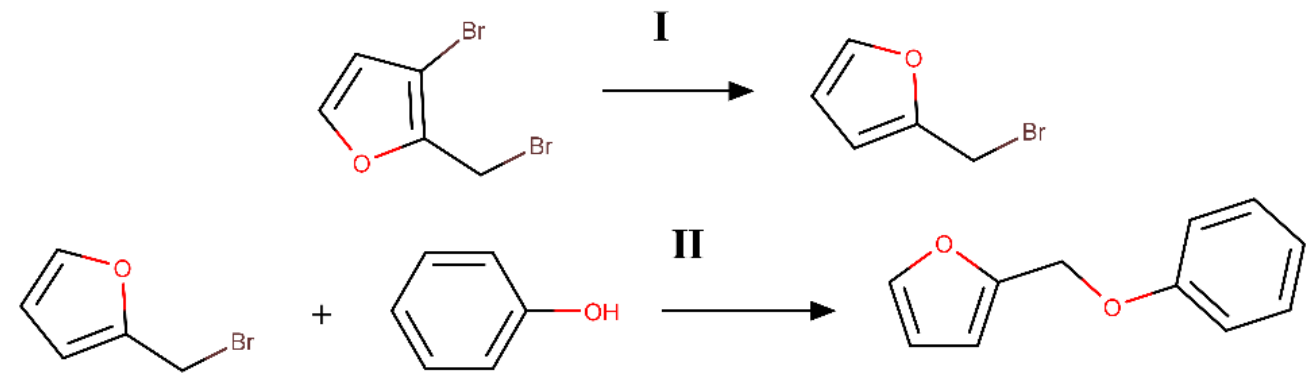

Source: Own Authorship.

The synthetic route of the compound ZINC12 is similar to that of the compound ZINC1 (Figure 17), in this route only one synthesis step is necessary, the reaction of forfural with aniline according to the literature procedures (Matusiak et al., 2013), its score in the retro synthesis was 0.8 .

Figure 17 - Theoretical route to obtain the ZINC12 compound.

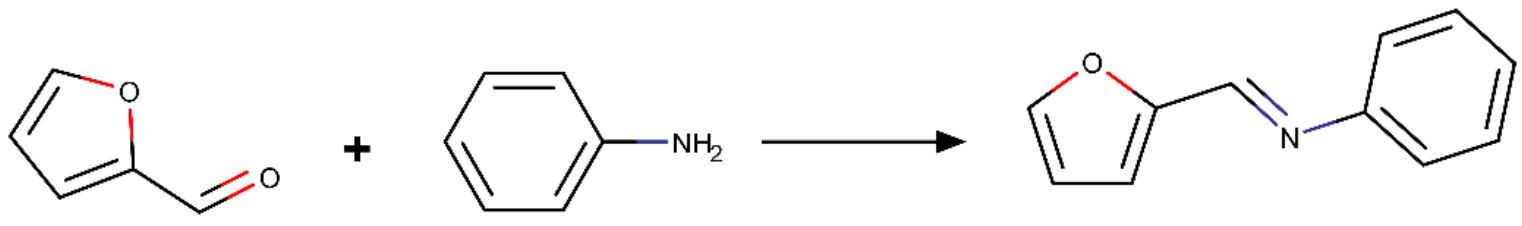

Source: Own Authorship.

The synthetic route proposed for the compound ZINC14 (Figure 18) occurs through the reaction of the solution of (1,3,4-Oxadiazol-2-yl)methanol added to phosphorus oxychloride and the mixture is stirred at room temperature for a period of 6 hours (Pahutski et al., 2015) resulting in 2-(Chloromethyl)-1,3,4-oxadiazole which in turn used the methodology of Mohanazadeh e Aghvami (2007) to obtain the compound ZINC14. His score on the spay server was 0.8.

Figure 18 - Theoretical route to obtain the ZINC14 compound.

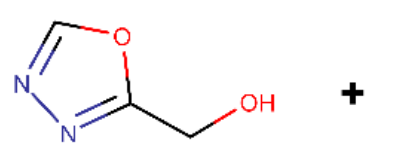<smiles>OP(Cl)(Cl)(Cl)Cl</smiles><smiles></smiles>
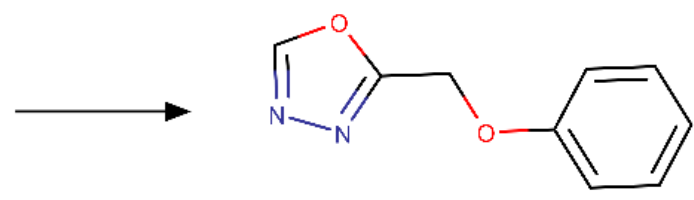

Source: Own Authorship.

The score obtained for the compound ZINC20 was 0.9, its route is similar to the route of the compounds ZINC1 and ZINC12 where forfural is part of the reaction with 3-Hydroxypyridine to obtain the compound studied (figure 19) based on the methodology of catalyzed oxidative esterification obtained from the literature (Zhang et al., 2011). 
Figure 19 - Theoretical route to obtain the ZINC20 compound.
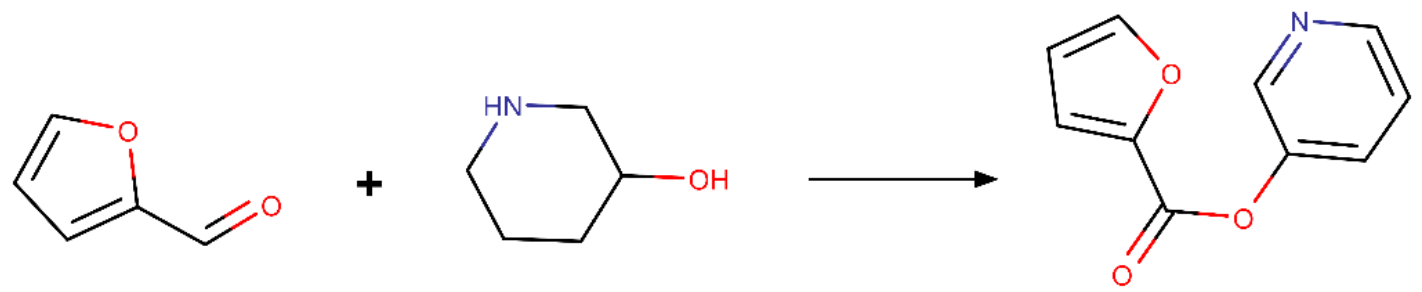

Source: Own Authorship

\section{Conclusion}

Through the virtual screening procedure based on pharmacophores, it was possible to obtain several structures where 5 of them (ZINC1, ZINC4, ZINC12, ZINC14 and ZINC20) were selected for further investigation.

ADMET's predictions showed that the structures are similar to the commercial drugs used in the comparison. Molecular docking indicated the ZINC12 molecule as the most promising in this study, presenting a binding energy of -18.59 $\mathrm{KJ}_{\mathrm{mol}}{ }^{-1}$, favoring its interaction with the Ebolavirus glycoprotein and an inhibitory constant of $555.9 \mu \mathrm{M}$. The molecular dynamics study thus demonstrating its inhibitory potential for EBOV GP. The synthetic route showed ways to obtain the compounds that could be tested.

Future researches are needed to prove the action of the selected structures, in vitro studies would be recommended considering the structures demonstrated here with virus cell cultures by specialized laboratories.

\section{References}

Anders, E., Koch, R., \& Freunscht, P. (1993). Optimization and application of lithium parameters for PM3. Journal of computational chemistry, 14(11), 13011312 .

Antal Jr, M. J., Leesomboon, T., Mok, W. S., \& Richards, G. N. (1991). Mechanism of formation of 2-furaldehyde from D-xylose. Carbohydrate Research, $217,71-85$.

Arooj, M., Sakkiah, S., Kim, S., Arulalapperumal, V., \& Lee, K. W. (2013). A combination of receptor-based pharmacophore modeling \& QM techniques for identification of human chymase inhibitors. PLoS One, 8(4), e63030.

Ault, B. S. (2018). Matrix Isolation Spectroscopic Studies: Thermal and Soft Photochemical Bimolecular Reactions. In Frontiers and Advances in Molecular Spectroscopy (pp. 667-712). Elsevier.

Azam, S. S., \& Abbasi, S. W. (2013). Molecular docking studies for the identification of novel melatoninergic inhibitors for acetylserotonin-Omethyltransferase using different docking routines. Theoretical Biology and Medical Modelling, 10(1), 1-16.

Azeredo, F. J., Uchôa, F. D. T., \& Costa, T. D. (2009). Papel da glicoproteína-P na farmacocinética e nas interações medicamentosas. Rev Bras Farm, 90(4), 321-326.

Baize, S., Pannetier, D., Oestereich, L., Rieger, T., Koivogui, L., Magassouba, N. F., ... \& Günther, S. (2014). Emergence of Zaire Ebola virus disease in Guinea. New England Journal of Medicine, 371(15), 1418-1425.

Balimane, P. V., Chong, S., \& Morrison, R. A. (2000). Current methodologies used for evaluation of intestinal permeability and absorption. Journal of pharmacological and toxicological methods, 44(1), 301-312.

Barreiro, E. J., \& Fraga, C. A. M. (2014). Química Medicinal-: As bases moleculares da ação dos fármacos. Artmed Editora.

Bastos, R. S., Sousa, C. S., Oliveira, J. S., da Silva, M. H. V., Lima, F. D. C. A., \& Rocha, J. A. (2020). Prospecção de Proteínas do Novo Coronavírus Covid2019 e Potencial da Bioinformática na Busca de Novas Drogas Promissoras. Cadernos de Prospecção, 13(2 COVID-19), 347.

Beaulieu, D., \& Ohemeng, K. A. (1999). Patents on bacterial tRNA synthetase inhibitors: January 1996 to March 1999. Expert Opinion on Therapeutic Patents, 9(8), 1021-1028.

Beeching, N. J., Fenech, M., \& Houlihan, C. F. (2014). Ebola virus disease. BMJ 349: g7348. 
Research, Society and Development, v. 11, n. 2, e45311226034, 2022

(CC BY 4.0) | ISSN 2525-3409 | DOI: http://dx.doi.org/10.33448/rsd-v11i2.26034

Benet, L. Z., \& Hoener, B. A. (2002). Changes in plasma protein binding have little clinical relevance. Clinical Pharmacology \& Therapeutics, 71(3), 115121.

Berman, H. M., Battistuz, T., Bhat, T. N., Bluhm, W. F., Bourne, P. E., Burkhardt, K., ... \& Zardecki, C. (2002). The protein data bank. Acta Crystallographica Section D: Biological Crystallography, 58(6), 899-907.

Bissantz, C., Folkers, G., \& Rognan, D. (2000). Protein-based virtual screening of chemical databases. 1. Evaluation of different docking/scoring combinations. Journal of medicinal chemistry, 43(25), 4759-4767.

Braga, E. J., Corpe, B. T., Marinho, M. M., \& Marinho, E. S. (2016). Molecular electrostatic potential surface, HOMO-LUMO, and computational analysis of synthetic drug Rilpivirine. Int. J. Sci. Eng. Res, 7(7), 315-319.

Brehm, M. A., Bortell, R., Verma, M., Shultz, L. D., \& Greiner, D. L. (2016). Humanized mice in translational immunology. Translational immunology: mechanisms and pharmacological approaches, 285-326.

Breman, J. G., Heymann, D. L., Lloyd, G., McCormick, J. B., Miatudila, M., Murphy, F. A., ... \& Johnson, K. M. (2016). Discovery and description of Ebola Zaire virus in 1976 and relevance to the West African epidemic during 2013-2016. The Journal of infectious diseases, 214(suppl_3), S93-S101.

Case, D. A., Cheatham III, T. E., Darden, T., Gohlke, H., Luo, R., Merz Jr, K. M., ... \& Woods, R. J. (2005). The Amber biomolecular simulation programs. Journal of computational chemistry, 26(16), 1668-1688.

Castillo-Garit, J. A., Marrero-Ponce, Y., Torrens, F., \& García-Domenech, R. (2008). Estimation of ADME properties in drug discovery: predicting Caco-2 cell permeability using atom-based stochastic and non-stochastic linear indices. Journal of pharmaceutical sciences, 97(5), 1946-1976.

Cruz, J. V., Serafim, R. B., da Silva, G. M., Giuliatti, S., Rosa, J. M., Neto, M. F. A., ... \& Santos, C. B. (2018). Computational design of new protein kinase 2 inhibitors for the treatment of inflammatory diseases using QSAR, pharmacophore-structure-based virtual screening, and molecular dynamics. Journal of molecular modeling, 24(9), 1-16.

Csizmadia, P. (1999). MarvinSketch and MarvinView: molecule applets for the World Wide Web.

Da Silva Costa, J., da Silva Lopes Costa, K., Cruz, J. V., da Silva Ramos, R., Silva, L. B., Do Socorro Barros Brasil, D., ... \& da Cruz Macedo, W. J. (2018). Virtual screening and statistical analysis in the design of new caffeine analogues molecules with potential epithelial anticancer activity. Current pharmaceutical design, 24(5), 576-594.

De Oliveira, A. M. (2018). Introdução à modelagem Molecular para Química, Engenharia e Biomédicas: fundamentos e exercícios. Appris Editora e Livraria Eireli-ME.

Desai, C. (2016). Meyler's side effects of drugs: The international encyclopedia of adverse drug reactions and interactions. Indian Journal of Pharmacology, 48(2), 224.

Dezani, T. M., Dezani, A. B., da Silva Junior, J. B., \& dos Reis Serra, C. H. (2016). Single-Pass Intestinal Perfusion (SPIP) and prediction of fraction absorbed and permeability in humans: A study with antiretroviral drugs. European Journal of Pharmaceutics and Biopharmaceutics, 104, 131-139.

Dos Santos, K. L., Cruz, J. N., Silva, L. B., Ramos, R. S., Neto, M. F., Lobato, C. C., ... \& Santos, C. B. (2020). Identification of novel chemical entities for adenosine receptor type 2a using molecular modeling approaches. Molecules, 25(5), 1245.

Feldmann, H., \& Geisbert, T. W. (2011). Ebola haemorrhagic fever. The Lancet, 377(9768), 849-862.

Gasteiger, J., \& Marsili, M. (1980). Iterative partial equalization of orbital electronegativity—a rapid access to atomic charges. Tetrahedron, 36(22), 32193228.

Gujjula, K. R. (2008). Prediction and comparison of hiv-1 protease inhibitor binding energies by various molecular docking methods (Doctoral dissertation).

Irvine, J. D., Takahashi, L., Lockhart, K., Cheong, J., Tolan, J. W., Selick, H. E., \& Grove, J. R. (1999). MDCK (Madin-Darby canine kidney) cells: a tool for membrane permeability screening. Journal of pharmaceutical sciences, 88(1), 28-33.

Jacoby, H. I. (2017). Gastric Emptying.

Johns, P. (2014). Clinical Neuroscience E-Book. Elsevier Health Sciences.

Khabbaz, R., Bell, B. P., Schuchat, A., Ostroff, S. M., Moseley, R., Levitt, A., \& Hughes, J. M. (2015). Emerging and reemerging infectious disease threats. Mandell, Douglas, and Bennett's principles and practice of infectious diseases, 158.

Koes, D. R. (2018). The Pharmit backend: A computer systems approach to enabling interactive online drug discovery. IBM journal of research and development, 62(6), 3-1.

La Regina, G., Gatti, V., Piscitelli, F., \& Silvestri, R. (2011). Open vessel and cooling while heating microwave-assisted synthesis of pyridinyl N-aryl hydrazones. ACS combinatorial science, 13(1), 2-6.

Larkin, P. (2017). Infrared and Raman spectroscopy: principles and spectral interpretation. Elsevier.

Lee, S. K., Lee, I. H., Kim, H. J., Chang, G. S., Chung, J. E., \& No, K. T. (2003). The PreADME Approach: Web-based program for rapid prediction of physico-chemical, drug absorption and drug-like properties. EuroQSAR 2002 Designing Drugs and Crop Protectants: processes, problems and solutions, 2003, 418-420. 
Research, Society and Development, v. 11, n. 2, e45311226034, 2022

(CC BY 4.0) | ISSN 2525-3409 | DOI: http://dx.doi.org/10.33448/rsd-v11i2.26034

Loprinzi, C. L., Barton, D. L., \& Qin, R. (2011). Nonestrogenic management of hot flashes. Journal of Clinical Oncology, 29(29), $3842-3846$.

Ma, X. L., Chen, C., \& Yang, J. (2005). Predictive model of blood-brain barrier penetration of organic compounds. Acta Pharmacologica Sinica, 26(4), 500512.

Maier, J. A., Martinez, C., Kasavajhala, K., Wickstrom, L., Hauser, K. E., \& Simmerling, C. (2015). ff14SB: improving the accuracy of protein side chain and backbone parameters from ff99SB. Journal of chemical theory and computation, 11(8), 3696-3713.

Mali, S. N., \& Chaudhari, H. K. (2019). Molecular modelling studies on adamantane-based Ebola virus GP-1 inhibitors using docking, pharmacophore and 3D-QSAR. SAR and QSAR in Environmental Research, 30(3), 161-180.

Mamman, A. S., Lee, J. M., Kim, Y. C., Hwang, I. T., Park, N. J., Hwang, Y. K., ... \& Hwang, J. S. (2008). Furfural: Hemicellulose/xylosederived biochemical. Biofuels, Bioproducts and Biorefining: Innovation for a sustainable economy, 2(5), 438-454.

Marcolin, M. A., Cantarelli, M. D. G., \& Garcia Junior, M. (2004). Interações farmacológicas entre medicações clínicas e psiquiátricas. Archives of Clinical Psychiatry (São Paulo), 31, 70-81.

Matusiak, A., Lewkowski, J., Rychter, P., \& Biczak, R. (2013). Phytotoxicity of new furan-derived aminophosphonic acids, N-aryl furaldimines and 5nitrofuraldimine. Journal of agricultural and food chemistry, 61(32), 7673-7678.

Mendonça, M. C. P. (2016). Óxido de grafeno e sistema nervoso central= avaliação dos efeitos na barreira hematoencefálica e perfil nanotoxicológico= Graphene oxide and central nervous system: evaluation of effects on blood brain barrier and nanotoxicological profile.

Moda, T. L. (2007). Desenvolvimento de modelos in silico de propriedades de ADME para triagem de novos candidatos a fármacos. São Paulo, Brazil: Universidade de São Paulo.

Mohanazadeh, F., \& Aghvami, M. (2007). Ionic liquids as reagent and reaction medium: Preparation of alkyl aryl ethers. Monatshefte für Chemie-Chemical Monthly, 138(1), 47-49.

Morris, G. M., Goodsell, D. S., Halliday, R. S., Huey, R., Hart, W. E., Belew, R. K., \& Olson, A. J. (1998). Automated docking using a Lamarckian genetic algorithm and an empirical binding free energy function. Journal of computational chemistry, 19(14), 1639-1662.

Morris, G. M., Huey, R., Lindstrom, W., Sanner, M. F., Belew, R. K., Goodsell, D. S., \& Olson, A. J. (2009). AutoDock4 and AutoDockTools4: Automated docking with selective receptor flexibility. Journal of computational chemistry, 30(16), 2785-2791.

Mukund, V., Behera, S. K., Alam, A., \& Nagaraju, G. P. (2019). Molecular docking analysis of nuclear factor- $\kappa$ B and genistein interaction in the context of breast cancer. Bioinformation, 15(1), 11.

Naz, A., Bano, K., Bano, F., Ghafoor, N. A., \& Akhtar, N. (2009). Conformational analysis (geometry optimization) of nucleosidic antitumor antibiotic showdomycin by Arguslab 4 software. Pakistan journal of pharmaceutical sciences, 22(1).

Nimlos, M. R., Qian, X., Davis, M., Himmel, M. E., \& Johnson, D. K. (2006). Energetics of xylose decomposition as determined using quantum mechanics modeling. The Journal of Physical Chemistry A, 110(42), 11824-11838.

Normant Annales de Chimie (Cachan, France), 1942, vol. <11>17, p. 335,346

Nova, A., \& Maseras, F. (2013). Enantioselective Synthesis. In Comprehensive Inorganic Chemistry II (Second Edition): From Elements to Applications (pp. 807-831).

Orellana, M., \& Guajardo, V. (2004). Actividad del citocromo P450 y su alteración en diversas patologías. Revista médica de Chile, 132(1), 85-94.

Ortiz, D. M., Carranza, R. C., Ramírez, A. M. D., \& Mejía, A. V. (2012). Modulación de la expresión de enzimas del citocromo P450 hepáticas durante las etapas fetal y pediátrica. Revista de Educación Bioquímica, 31(2), 60-71.

Oso, B. J., Adeoye, A. O., \& Olaoye, I. F. (2020). Pharmacoinformatics and hypothetical studies on allicin, curcumin, and gingerol as potential candidates against COVID-19-associated proteases. Journal of Biomolecular Structure and Dynamics, 1-12.

Ostroff, D., McDade, J., LeDuc, J., \& Hughes, J. M. (2005). Emerging and reemerging infectious disease threats. Principles and practice of infectious disease. Philadelphia, Elsevier Churchill Livingstone, 173-192.

Ouakki, M., Galai, M., Rbaa, M., Abousalem, A. S., Lakhrissi, B., Rifi, E. H., \& Cherkaoui, M. (2019). Quantum chemical and experimental evaluation of the inhibitory action of two imidazole derivatives on mild steel corrosion in sulphuric acid medium. Heliyon, 5(11), e02759.

Pahutski, T. F., Lahm, G. P., Kar, M., \& Ahmad, O. K. (2015). U.S. Patent No. 9,113,631. Washington, DC: U.S. Patent and Trademark Office.

Parrot, M., Tajmouati, H., da Silva, V. B. R., Atwood, B. R., Fourcade, R., Gasthon-Mathé, Y., ... \& Perron, Q. (2021). Integrating synthetic accessibility with AI-based generative drug design.

Pereira, D. H., La Porta, F. A., Santiago, R. T., Garcia, D. R., \& Ramalho, T. C. (2016). Novas perspectivas sobre o papel dos orbitais moleculares de fronteira no estudo da reatividade química: uma revisão. Revista Virtual de Química, 8(2), 425-453.

Pettersen, E. F., Goddard, T. D., Huang, C. C., Couch, G. S., Greenblatt, D. M., Meng, E. C., \& Ferrin, T. E. (2004). UCSF Chimera-a visualization system for exploratory research and analysis. Journal of computational chemistry, 25(13), 1605-1612. 
Research, Society and Development, v. 11, n. 2, e45311226034, 2022

(CC BY 4.0) | ISSN 2525-3409 | DOI: http://dx.doi.org/10.33448/rsd-v11i2.26034

Plewczynski, D., Łaźniewski, M., Augustyniak, R., \& Ginalski, K. (2011). Can we trust docking results? Evaluation of seven commonly used programs on PDBbind database. Journal of computational chemistry, 32(4), 742-755.

Price, D. J., \& Brooks III, C. L. (2004). A modified TIP3P water potential for simulation with Ewald summation. The Journal of chemical physics, 121(20), 10096-10103.

Rajapaksha, H., Perera, B. T., Meepage, J., Perera, R. T., \& Dissanayake, C. (2020). Mitigate the cytokine storm due to the severe COVID-19: A computational investigation of possible allosteric inhibitory actions on IL-6R and IL-1R using selected phytochemicals. European Journal of Chemistry, $11(4), 351-363$

Ramalingam, S., Babu, P. D. S., Periandy, S., \& Fereyduni, E. (2011). Vibrational investigation, molecular orbital studies and molecular electrostatic potential map analysis on 3-chlorobenzoic acid using hybrid computational calculations. Spectrochimica Acta Part A: Molecular and Biomolecular Spectroscopy, 84(1), 210-220.

Ramírez, D., \& Caballero, J. (2018). Is it reliable to take the molecular docking top scoring position as the best solution without considering available structural data?. Molecules, 23(5), 1038 .

Reeve, E. C. (Ed.). (2014). Encyclopedia of genetics. Routledge.

Ren, J., Zhao, Y., Fry, E. E., \& Stuart, D. I. (2018). Target identification and mode of action of four chemically divergent drugs against ebolavirus infection. Journal of medicinal chemistry, 61(3), 724-733.

Richman, D. D., \& Nathanson, N. (2016). Antiviral therapy. In Viral pathogenesis (pp. 271-287). Academic Press.

Rocha, J. A., Rego, N. C., Carvalho, B. T., Silva, F. I., Sousa, J. A., Ramos, R. M., ... \& Lima, F. C. (2018). Computational quantum chemistry, molecular docking, and ADMET predictions of imidazole alkaloids of Pilocarpus microphyllus with schistosomicidal properties. PloS one, 13(6), e0198476.

Roe, D. R., \& Cheatham III, T. E. (2013). PTRAJ and CPPTRAJ: software for processing and analysis of molecular dynamics trajectory data. Journal of chemical theory and computation, 9(7), 3084-3095.

Rothman, R. B., Baumann, M. H., Prisinzano, T. E., \& Newman, A. H. (2008). Dopamine transport inhibitors based on GBR12909 and benztropine as potential medications to treat cocaine addiction. Biochemical pharmacology, 75(1), 2-16.

Rougeron, V., Feldmann, H., Grard, G., Becker, S., \& Leroy, E. M. (2015). Ebola and Marburg haemorrhagic fever. Journal of Clinical Virology, 64, 111-119.

Sambuy, Y., De Angelis, I., Ranaldi, G., Scarino, M. L., Stammati, A., \& Zucco, F. (2005). The Caco-2 cell line as a model of the intestinal barrier: influence of cell and culture-related factors on Caco-2 cell functional characteristics. Cell biology and toxicology, 21(1), 1-26.

Santos, J. L. (2007). Avaliação da atividade mutagênica da talidomida pelo teste de ames. Revista Eletrônica de Farmácia, 4(2).

Schneidman-Duhovny, D., Dror, O., Inbar, Y., Nussinov, R., \& Wolfson, H. J. (2008). PharmaGist: a webserver for ligand-based pharmacophore detection. Nucleic acids research, 36(supp1_2), W223-W228.

Singh, K., Sharma, P. K., Dhawan, S. N., \& Singh, S. P. (2005). Synthesis and characterisation of some novel indeno [1, 2-c] pyrazoles. Journal of Chemical Research, 2005(8), 526-529.

Souza, R. L. D. (2015). Aplicação da técnica de ancoragem molecular na otimização do fármaco hipoglicemiante metformina. Centr Uni Luter Palm. Palmas.

Studio, D. (2008). Discovery Studio. Accelrys [2.1].

Towner, J. S., Pourrut, X., Albariño, C. G., Nkogue, C. N., Bird, B. H., Grard, G., ... \& Leroy, E. M. (2007). Marburg virus infection detected in a common African bat. PloS one, 2(8), e764.

Van Harten, J. (1993). Clinical pharmacokinetics of selective serotonin reuptake inhibitors. Clinical pharmacokinetics, 24(3), 203-220.

Vieira, J. B., Braga, F. S., Lobato, C. C., Santos, C. F., Costa, J. S., Bittencourt, J. A. H., ... \& Santos, C. B. R. (2014). A QSAR, pharmacokinetic and toxicological study of new artemisinin compounds with anticancer activity. Molecules, 19(8), 10670-10697.

Wadapurkar, R. M., Shilpa, M. D., Katti, A. K. S., \& Sulochana, M. B. (2018). In silico drug design for Staphylococcus aureus and development of hostpathogen interaction network. Informatics in Medicine Unlocked, 10, 58-70.

Wang, B., \& Merz, K. M. (2006). A fast QM/MM (quantum mechanical/molecular mechanical) approach to calculate nuclear magnetic resonance chemical shifts for macromolecules. Journal of chemical theory and computation, 2(1), 209-215.

Wenthur, C. J., Gentry, P. R., Mathews, T. P., \& Lindsley, C. W. (2014). Drugs for allosteric sites on receptors. Annual review of pharmacology and toxicology, 54, 165-184.

Wermuth, C. G., Villoutreix, B., Grisoni, S., Olivier, A., \& Rocher, J. P. (2015). Strategies in the search for new lead compounds or original working hypotheses. In The practice of medicinal chemistry (pp. 73-99). Academic Press.

Wishart, D. S., Feunang, Y. D., Guo, A. C., Lo, E. J., Marcu, A., Grant, J. R., ... \& Wilson, M. (2018). DrugBank 5.0: a major update to the DrugBank database for 2018. Nucleic acids research, 46(D1), D1074-D1082.

Wold, E. A., Chen, J., Cunningham, K. A., \& Zhou, J. (2018). Allosteric modulation of class A GPCRs: targets, agents, and emerging concepts. Journal of medicinal chemistry, 62(1), 88-127. 
Research, Society and Development, v. 11, n. 2, e45311226034, 2022

(CC BY 4.0) | ISSN 2525-3409 | DOI: http://dx.doi.org/10.33448/rsd-v11i2.26034

WORLD HEALTH ORGANIZATION. (2020). Doença do vírus Ebola. Retrieved December 9, 2021, from https://www.who.int/news-room/factsheets/detail/ebola-virus-disease

Yamashita, S., Furubayashi, T., Kataoka, M., Sakane, T., Sezaki, H., \& Tokuda, H. (2000). Optimized conditions for prediction of intestinal drug permeability using Caco-2 cells. European journal of pharmaceutical sciences, 10(3), 195-204.

Yan, A., Wang, Z., \& Cai, Z. (2008). Prediction of human intestinal absorption by GA feature selection and support vector machine regression. International journal of molecular sciences, 9(10), 1961-1976.

Yang, C. Y. (2015). Identification of potential small molecule allosteric modulator sites on IL-1R1 ectodomain using accelerated conformational sampling method. PloS one, 10(2), e0118671.

Yang, J. F., Wang, F., Chen, Y. Z., Hao, G. F., \& Yang, G. F. (2020). LARMD: integration of bioinformatic resources to profile ligand-driven protein dynamics with a case on the activation of estrogen receptor. Briefings in Bioinformatics, 21(6), 2206-2218.

Yokoi, K., Yada, H., Yoshimoto, D., Hakuno, D., Miyazaki, K., \& Adachi, T. (2013). A case of drug-induced interstitial pneumonia caused by repeated exposure to bepridil. Journal of Arrhythmia, 29(1), 39-42.

Zeitsch, K. J. (2000). The chemistry and technology of furfural and its many by-products. Elsevier.

Zhang, M., Zhang, S., Zhang, G., Chen, F., \& Cheng, J. (2011). Palladium/NHC-catalyzed oxidative esterification of aldehydes with phenols. Tetrahedron Letters, 52(19), 2480-2483. 